\title{
Benthic and fish aggregation inside an offshore wind farm: Which effects on the trophic web functioning?
}

\author{
Raoux Aurore ${ }^{1,2,{ }^{*}}$, Tecchio Samuele ${ }^{1}$, Pezy Jean-Philippe ${ }^{2}$, Lassalle Géraldine ${ }^{3}$, Degraer Steven ${ }^{4}$, \\ Wilhelmsson Dan ${ }^{5}$, Cachera Marie ${ }^{7}$, Ernande Bruno ${ }^{6}$, Le Guen Camille ${ }^{1}$, Haraldsson Matilda ${ }^{1}$, \\ Grangeré Karine ${ }^{1}$, Le Loc'h François ${ }^{7}$, Dauvin Jean-Claude ${ }^{2}$, Niquil Nathalie ${ }^{1}$
}

\footnotetext{
${ }^{1}$ Normandie Université UNICAEN, UMR BOREA (MNHN, UPMC, UCN, CNRS-7208, IRD-207) CS 14032, 14000 Caen, France

${ }^{2}$ Normandie Université UNICAEN, UMR M2C (UCN, UR, CNRS-6143), 24 rue des Tilleuls, 14000 Caen Cedex, France

${ }^{3}$ IRSTEA, UR EABX (Aquatic Ecosystems and Global Changes), 50 avenue de Verdun, 33612 Cestas Cedex, France

${ }^{4}$ Royal Belgian Institute of Natural Sciences (RBINS), Operational Directorate Natural Environment (OD Nature), Marine Ecology and Management (MARECO) Gulledelle 100, 1200 Brussels, Belgium

${ }^{5}$ The Royal Swedish Academy of Sciences Box 50005, SE-104 05 Stockholm, Sweden

${ }^{6}$ IFREMER, Laboratoire Ressources Halieutiques, 150 quai Gambetta, BP 699, 62321 Boulogne sur Mer, France

${ }^{7}$ Laboratoire des Sciences de I'Environnement Marin, UMR 6539 LEMAR (CNRS/UBO/IRD/Ifremer), Institut Universitaire Européen de la Mer (IUEM), Technopôle Brest-Iroise, Rue Dumont d'Urville, 29280 Plouzané, France

*Corresponding author : Aurore Raoux, email address : aurore.raoux@unicaen.fr
}

\begin{abstract}
:
As part of the energy transition, the French government is planning the construction of three offshore wind farms in Normandy (Bay of Seine and eastern part of the English Channel, north-western France) in the next years. These offshore wind farms will be integrated into an ecosystem already facing multiple anthropogenic disturbances such as maritime transport, fisheries, oyster and mussel farming, and sediment dredging. Currently no integrated, ecosystem-based study on the effects of the construction and exploitation of offshore wind farms exists, where biological approaches generally focused on the conservation of some valuable species or groups of species. Complementary trophic web modelling tools were applied to the Bay of Seine ecosystem (to the $50 \mathrm{~km} 2$ area covered by the wind farm) to analyse the potential impacts of benthos and fish aggregation caused by the introduction of additional hard substrates from the piles and the turbine scour protections. An Ecopath ecosystem model composed of 37 compartments, from phytoplankton to seabirds, was built to describe the situation "before" the construction of the wind farm. Then, an Ecosim projection over 30 years was performed after increasing the biomass of targeted benthic and fish compartments. Ecological Network Analysis (ENA) indices were calculated for the two periods, "before" and "after", to compare network functioning and the overall structural properties of the food web. Our main results showed (1) that the total ecosystem activity, the overall system omnivory (proportion of generalist feeders), and the recycling increased after the construction of the wind farm; (2) that higher trophic levels such as piscivorous fish
\end{abstract}


species, marine mammals, and seabirds responded positively to the aggregation of biomass on piles and turbine scour protections; and (3) a change in keystone groups after the construction towards more structuring and dominant compartments. Nonetheless, these changes could be considered as limited impacts of the wind farm installation on this coastal trophic web structure and functioning.

\section{Highlights}

- Ecopath models before/after an offshore wind farm were built. Possible reef effect would increase total system biomass by $55 \%$. Bivalves build-up would lead to a food web dominated by detritivory. - Benthos and keystone fish biomass increases attracted apex predators.

Keywords: Marine renewable energies, Reef effect, Wind farm, Ecopath with Ecosim, Ecosystembased approach 


\section{INTRODUCTION}

Humanity's ever growing energy demands have translated into an increase in fossil fuel combustion and greenhouse gases emissions and, consequently, into global climate changes (OSPAR, 2008; IPCC, 2014). A new focus on renewable energy source research and development arose during the last decades to counter this trend. The European Union (EU) has set a target of $20 \%$ of energetic consumption derived from renewable energy sources by 2020 (Directive 2009/28/EC). With more than 11 million $\mathrm{km}^{2}$ of waters under its jurisdiction, France holds a huge natural potential for marine renewable energy (MEDDE 2011). Currently, the construction of six offshore wind farms is planned in metropolitan France. Among them, three should be built in the central-eastern part of the English Channel: the Courseulles-sur-mer ( $50 \mathrm{~km}^{2}, 75$ wind turbines), the Fécamp ( $\sim 5 \mathrm{~km}^{2}, 83$ wind turbines) and the Tréport ( $\sim 7 \mathrm{~km}^{2}, 62$ wind turbines) offshore wind farms. The implementation of this type of infrastructure is a challenge for developers from technical, legal, social, and environmental points of view. Indeed, these offshore wind farms will be integrated into ecosystems already subjected to a growing number of anthropogenic disturbances such as pollution, transport, fishing, aquaculture, aggregate extraction, or sediment dredging and deposit.

Concern about the potential environmental impacts generated by these new structures on marine ecosystems arose from this development (Lindeboom et al., 2011; Bailey et al., 2014). The exploration, construction, operation, and decommissioning of offshore wind farms can indeed be responsible for temporary and/or permanent impacts on marine ecosystems such as the destruction of seabed or the disturbance of fish and marine mammal populations (Shields et al., 2014; OSPAR, 2008; Mueller-Blenkle et al., 2010). During the construction phase, if special care is taken to protect rare habitats and spatial and temporal habitat use by sensitive species, effects can be kept relatively small or negligible (e.g. Wilhelmsson et al. 2010). During the operational phase, the anticipated and recorded disturbances caused by noise, vibrations and the electromagnetic fields are also in most cases considered to be of minor importance to the marine environment, at least to date (Westerberg et al., 2008; Petersen and Malm, 2006, Wilhelmsson et al. 2010). However, a noteworthy effect of the introduction of turbines with their associated scour protection is the creation of new habitats and shelters that will be immediately colonized by several marine species resulting in an additional source of food for higher trophic levels (Bergström et al., 2013). This effect, generally known as the "reef effect", is considered as one of the most important effect on the marine environment generated by the construction of offshore wind farms (Peterson and Malm, 2006; Langhamer, 2012; De Mesel et al., 2015). The reef effect has been described for epibenthic and demersal fauna as well as on bentho-pelagic fish (including commercial species) in the direct proximity of wind farm foundations (Wilhelmsson et al., 2006; Tougard et al., 2006; Wilhelmsson and Malm, 2008; Maar et al., 2009; Reubens et al., 2011; Leonhard et al., 2011; Lindeboom et al., 2011; Bergström et al., 2013; Reubens et al., 2013; Reubens et al., 2014; Degraer et al., 2014). The reef effect has also been demonstrated for other anthropogenic 
structures such as shipwrecks and oil platforms (Wolfson et al., 1979; Love et al., 1994, 1999; Wilhelmsson et al., 2006). The choice of material and the shape of the structures introduced in the marine environment both play an important role during the colonization process (e.g. Andersson et al., 2010). All these previous studies provide a vast amount of data on environmental effects at the species or community scales. However, the propagation of the reef effect at the ecosystem scale, impacting the structure and functioning of food webs remains unclear (Boehlert and Gill, 2010).

Until now, there is no holistic study on the effects of the construction and operation of offshore wind farms on an ecosystem taken as a whole. Here, we propose to develop a holistic view of offshore wind farm impacts on ecosystems functioning through the use of trophic web modelling tools. Our work will provide information on the food web change in response to the construction and operation of marine energy infrastructures, information which is essential to the sustainable development and management of renewable energy sources. The main feature of this work will be to propose a methodology that is complementary to what it is currently applied in Environmental Impact Assessments by using: (1) a holistic approach in which the ecosystem represents the management unit, (2) a functional perspective based on flows of energy circulating between ecosystem components, and (3) a high level of functional diversity to describe the food web.

Among the different existing modelling approaches, Ecopath with Ecosim (EwE) has been intensively developed and used over the last three decades and was applied on hundreds of aquatic ecosystems throughout the world (Polovina, 1984; Christensen and Walters, 2004; Christensen et al., 2008). This approach, in which all biotic components of the system are considered the same time, provides measures of the ecosystem emergent properties through the calculation of Ecological Network Analysis (ENA) indices (Ulanowicz, 1986). These joint analyses have been frequently applied to coastal and marine systems to assess changes in their functioning in response to environmental perturbations (Ortiz and Wolff 2002, Rybarczyk et al., 2003; Patricio et al., 2006; Niquil et al., 2012; Tecchio et al., 2013, 2015). Some ENA indices, such as the redundancy, have also been linked to notions of stability (Christensen et al., 2005) such as the resilience of trophic webs to perturbations (Heymans et al., 2007). Finally, ENA indices have also been proposed as trophic descriptors of ecosystem health for the EU Marine Strategy Framework Directive (Dame and Christian 2007; Niquil et al., 2012; Rombouts et al., 2013; Niquil et al., 2014).

The objective of the present study was to model the potential impacts of the construction and operation of the Courseulles-sur-mer (southern part of the Bay of Seine along the Calvados coast) offshore wind farm on the local trophic-web functioning. Special attention was paid on how benthos and fish aggregation caused by the introduction of additional hard substrates from the piles and the scour protections might lead to the development of an artificial reef system, and also what the consequences on the food-web functioning could 
113 be. To analyse the impact of additionally available hard substrates, an Ecopath model was first built to 114 describe the food web before the construction of the Courseulles-sur-mer offshore wind farm and then an 115 Ecosim model was derived to project over the next 30 years the ecosystem evolution after the forced increase 116 in biomass of some targeted benthic and fish compartments in relation to the wind farm construction. For 117 this, observations of species changes in wind farm areas obtained through extensive literature searches were 118 adapted to the Courseulles-sur-mer site based on expert knowledge. Two hypotheses regarding the food119 web functioning were particularly investigated with Ecosim simulations: (i) a system dominated by mussels 120 leads to a more detritivorous food web (Norling and Kautsky, 2008), and (ii) the increased biomass of benthic 121 invertebrates and fish, as generated by the reef effect, would attract apex predators (Lindeboom et al., 2011; 122 Henkel et al., 2014).This is, to our knowledge, the first attempt to study the potential impacts of the 123 construction and operation of an offshore wind farm on the local trophic web structure and functioning using 124 an integrated ecosystem modelling approach.

\section{MATERIAL AND METHODS}

\subsection{Study area}

127 The Bay of Seine, where the offshore wind farm will be built in the next years (from 2018) is located on the north-western French coast and opens onto the eastern English Channel (Fig. 1). The Bay of Seine forms an approximate quadrilateral of $5000 \mathrm{~km}^{2}$, with a mean depth of about $20 \mathrm{~m}$. The water depth never exceeds $35 \mathrm{~m}$. The maximum tidal range is $7.5 \mathrm{~m}$ in the eastern part of the Bay near the mouth of the Seine estuary. Tidal currents average between 1 and 2 knots in the southern sector of the Bay, and their intensity gradually diminishes toward the eastern Bay of Seine (Salomon and Breton, 1991, 1993). The distribution of superficial sediments and benthic communities is strongly correlated to these currents (Gentil and Cabioch, 1997; Dauvin, 2015). There is an offshore-inshore gradient in the Bay, with the dominant sediment offshore generally consisting in pebbles, gravel and coarse sands and the sediment inshore in the coastal zones consisting mostly of fine sands and muddy fine sands (Dauvin et al., 2007, 2015). Benthic communities of the Bay of Seine are well described in terms of composition and spatial distribution (Dauvin and Ruellet, 2008) and were demonstrated to be good indicators of ecosystem health (Garcia, 2011). Coastal marine, estuarine and mixed systems along the French coasts are predicted to be high sensitive to climatic variations (Goberville et al., 2010). The Bay of Seine ecosystem is already submitted to multiple anthropogenic disturbances such as maritime traffic, fishing, and sediment dredging (Dauvin et al., 2004). All these features make it a system at the crossroad of various influences, central for studying cumulative impacts on the functioning of marine ecosystems. 


\subsection{Courseulles-sur-mer offshore wind farm project}

145 The project is owned by "Eoliennes Offshore du Calvados", a subsidiary of Éolien Maritime France and wpd 146 Offshore. EMF was allowed to operate the offshore wind farm off from Courseulles-sur-mer by the Ministerial 147 Order of April $18^{\text {th }} 2012$. The proposed wind farm will be located 10 to $16 \mathrm{~km}$ offshore from the coast of 148 Calvados - Normandy. The depth range is 22-31 $\mathrm{m}$ at Lowest Astronomical Tide (LAT to be checked). The 149 wind farm will have a total area of approximately $50 \mathrm{~km}^{2}$ (Fig. 1). The wind farm will comprise $756 \mathrm{MW}$ 150 turbines giving a combinated nameplate capacity of $450 \mathrm{MW}$. The wind farm turbines will be connected via 151 an interarray network of $33 \mathrm{kV} \mathrm{AC}$ cables which will link at one offshore transformer substation located within 152 the wind farm. From this station power will be exported via two $225 \mathrm{kV}$ AC marine cables. The turbines are 153 supported by $7 \mathrm{~m}$ of diameter monopiles driven into the sea bed. The foot print of the 75 turbines foundation 154 and of the converter station will be $0.158 \mathrm{~km}^{2}$ or $0.03 \%$ of the overall wind farm area. Our work hypothesis 155 was that scour protections will be installed around the 75 turbines and the converter station and $33 \%$ of the 156 cables will be rock-dumped, thus the total additional surface would amount to $0.342 \mathrm{~km}^{2}$, or $0.72 \%$ of the 157 offshore wind farm area when considered in two dimensions. In calculating the biomasses changes we took 158 into account the actual "foot print" of the new structure: while in terms of surface it will be low, the 159 colonization of the structure will happen in three dimensions including the whole pillar. The production 160 generated by the wind park would cover the average annual electricity consumption of approximately 161630,000 people, i.e. around $40 \%$ of the inhabitants of the surrounding region of Normandy.

\subsection{Presentation of the trophic modelling approach}

164 The Ecopath with Ecosim (EwE) software (Polovina, 1984; Christensen and Walters, 2004; Christensen et al., 165 2008) was used to model the food web at the site of the construction of the future Courseulles-sur-mer 166 offshore wind farm. Among the different EwE modules, Ecopath is designed to build a snapshot of the ecosystem functioning while Ecosim allows simulating its dynamic evolution through time. Ecopath is a massbalance (i.e. neglecting year-to-year changes in biomass compared to flows), single-solution model (i.e. returning only one value per flow), that estimates fluxes between a set of established trophic compartments. Each compartment corresponds to a single species or a group of species similar in terms of predators, preys and of metabolic rates (i.e. trophic group). It is parameterised with biomasses (B, $\mathrm{gC}^{-\mathrm{m}^{-2}}$ ), production over biomass ratios $\left(P / B\right.$, year $\left.{ }^{-1}\right)$, consumption over biomass ratios $\left(Q / B, y^{-1}\right)$ and a diet matrix $(D C=$ diet composition) which establishes the interactions between predators and preys in the ecosystem. the production for each compartment in the system as a function of the consumption ratio $(\mathrm{Q} / \mathrm{B})$ of its 
predators $(\mathrm{j})$, the fishing mortality $\left(\mathrm{Yi}, \mathrm{gC} \cdot \mathrm{m}^{-2}\right)$, the net migration ( $\mathrm{Ei}$; emigration - immigration, year $\left.{ }^{-1}\right)$, the biomass accumulation (BAi, year ${ }^{-1}$ ), and its natural mortality (1-EEi). EE corresponds to the Ecotrophic Efficiency or the proportion of biomass consumed in the system for each compartment in the system.

$$
B\left(\frac{P}{B}\right)_{i}=\sum_{j} B_{j}\left(\frac{Q}{B}\right)_{j} D C_{i j}+Y_{i}+E_{i}+B A_{i}+B_{i}\left(\frac{P}{B}\right)_{i}\left(1-E E_{i}\right)
$$

The second equation (Eq. 2) describes the energy balance within a compartment.

$$
Q_{i}=P_{i}+R_{i}+U_{i}
$$

The energy balance of each group in equation 2 is assured by making consumption of the $i^{\text {th }}$ group (Qi) equal to the sum of its production $(\mathrm{Pi})$, respiration $\left(\mathrm{Ri}, \mathrm{gC} \cdot \mathrm{m}^{-2}\right)$, and excretion of unassimilated food (Ui).

\subsection{Parameterisation of the Ecopath model describing the situation before the wind farm} The selection and aggregation of functional groups included in the Ecopath model was based on biological and ecological characteristics of the species such as their food preference, size, and commercial importance as well as on data availability. On this basis, 37 groups were retained (Table 1, Fig. 2), two of which were seabirds, four marine mammals, eighteen fish, nine invertebrates, one zooplankton, one primary producers, one bacteria, and one detritus group.

$<$ Table 1>

$<$ Figure 2>

\subsubsection{Seabirds}

Abundance data were collected from the 41 boat surveys conducted by the Normandy Ornithological Group (GONm) on a monthly basis, from January 2008 to December 2010 (Morel, 2013). The Bay of Seine is on the migration route and wintering area for many marine birds. Consequently, the proportion of prey captured outside the area was considered as imports in seabird diets. The species observed inside the implantation area of the future Courseulles-sur-mer offshore wind farm were grouped into two categories according to their main feeding strategies. The "Plunge and pursuit divers" were composed of northern gannets (Sula basana), loon (Gavia sp.), auks (common mures Uria aalge, razorbills Alca torda), cormorant (Phalacrocorax carbo), and scoters (black scoter Melanitta nigra, White-winged scoter Melanitta fusca). The "surface feeders" were all gulls (herring gulls Larus argentatus, common gull Larus canus, lesser-backed gulls Larus fuscus, and great black-backed gulls Larus marinus). 
203

204

205

The mean body mass of these species were derived from Hunt et al. (2005). Conversion factors of 0.3 and 0.4 were used to convert wet weights into dry weights and then into carbon contents, respectively (Lassalle et al., 2011).

Daily consumption ratios were calculated according to the following empirical equation (Nilsson and Nilsson, 1976):

$$
\log \left(R_{c}\right)=-0.293+0.85 * \log _{10} \text { (body mass) }
$$

This value was then multiplied by 365 days and divided by the mean weight of the taxon to provide annual $\mathrm{Q} / \mathrm{B}$ ratio in year ${ }^{-1}$. The $\mathrm{P} / \mathrm{B}$ ratio for the two functional groups was based on estimates published in Nelson (1979). For these two groups, the diet compositions were retrieved from literature (Hunt et al., 2005). The proportion of prey captured outside the area was considered as imports in their diet (see Table 2 in Appendix A).

\subsubsection{Marine mammals}

Abundance data for bottlenose dolphins (Tursiops truncatus) and harbour porpoises (Phocoena phocoena) were collected from aerial surveys from November 2011 to August 2012 (Martinez et al., 2014). Abundance for harbour seals (Phoca vitulina) and grey seals (Halichoerus grypus) were derived from telemetric surveys from 2007 to 2013 (Martinez et al., 2014).

For each species, the mean body weight was calculated according to its maximum body length (Trites and Pauly, 1998). To convert wet weights into carbon contents, a conversion factor of 0.1 was used (Bradford Grieve et al., 2003). To estimate the $Q / B$ ratio, we used the metabolic rates and the daily consumption according to the empirical equations of Boyd (2002) and Spitz et al. (2010). The P/B ratios for these four species were taken from Christensen et al. (2009). Their diet compositions were defined according to Spitz et al. (2006). Based on the aerial surveys, marine mammal distributions cover large spatial scales far beyond the Bay of Seine limits. Consequently, the proportion of prey captured outside the area was considered as imports in their diet (see Table 2 in Appendix A).

\subsubsection{Fish compartments}

Abundance data for fish were collected from the GOV ("Grande Ouverture Verticale"= high opening) bottomtrawl survey conducted annually in October by IFREMER in the eastern English Channel and the south of the North Sea since 1988 (Channel Ground Fish Survey, CGFS). Data were averaged over 3 years (from 2010 to 2013). Fish were grouped into 6 functional groups: sharks and rays, gurnards, piscivorous, planktivorous, 
232 benthos feeders, and other flatfish. Moreover, mackerel (Scomber scombrus), European sea bass 233 (Dicentrarchus labrax), Atlantic cod (Gadus morhua), whiting (Merlangius merlangus), Atlantic horse mackerel (Trachurus trachurus), pouting (Trisopterus luscus), poor cod (Trisopterus minutus), European pilchard (Sardina pilchardus), European sprat (Sprattus sprattus) sea bream (Spondyliosoma cantharus), common sole (Solea solea), and European plaice (Pleuronectes platessa) formed 12 single-species compartments. These 12 species are either commercial species or species known to be attracted by the reef effect. Therefore, they were not aggregated with the other compartments in order to see more in details the potential impact of the MRE.

Fish wet body weights (originally in $\mathrm{kg} \mathrm{km}^{-2}$ ) were converted to carbon contents using a conversion factor of 0.11 (Oguz et al., 2008). Q/B and P/B ratios were taken from Mackinson and Daskalov (2007). The diet compositions were retrieved from the literature (Cachera 2013). Landings data were obtained from the Fisheries Information System of IFREMER (http://sih.ifremer.fr/).

\subsubsection{Invertebrate compartments}

245 Cephalopods

246 Abundance data (in kg. $\mathrm{km}^{-2}$ ) for cephalopods were also collected from the GOV bottom-trawl survey CGFS and averaged over 3 years (from 2010 to 2013). Cephalopods were divided into 2 groups: "Bentho-pelagic cephalopods" composed of Loligo sp. and Allotheuthis sp., and "Benthic cephalopods" composed of Sepia officinalis., Conversion factors of 0.192 and 0.402 were used to convert wet weights into dry weights and then into carbon contents, respectively (Brey et al., 2010). Q/B and P/B ratios were taken from Sanchez and Olaso (2004). Landings data were taken from the Fisheries Information System of IFREMER (http://sih.ifremer.fr/). Diet compositions were retrieved from the literature (De Pierrepont et al., 2005; Daly et al., 2001).

\section{Benthic invertebrates}

Benthic invertebrates were sampled with a $0.1 \mathrm{~m}^{2}$ Day grab in June 2009. Species were grouped into 4 compartments: "predators", "filter feeders", "bivalves" and "deposit feeders". Bivalves were not aggregated with the filter feeders to investigate in more details their importance in the functioning of the trophic web as well as to test the hypothesis of Norling and Kaustky (2008). In addition the above 4 groups, king scallop (Pecten maximus) was included as a single-species compartment given its economic value. Ash-free dry weights were converted to carbon contents using a conversion factor of 0.518 (Salonen et al., 1976 in Brey, 2001). P/B and Q/B were taken from Le Loc'h (2004) and Brey (2001), and diet compositions were taken from Rybarczyk and Elkaim (2003). 


\section{Suprabenthos}

The suprabenthos is defined as living organisms in the water layer immediately adjacent to the bottom that make daily vertical migrations and / or seasonal movements at varying distances from the bottom (Brunel et al., 1978) (e.g. gammarids, corophium). Abundance data were collected from Vallet (1997) that studied suprabenthos all across the English Channel. P/B and Q/B ratios were taken from Brey (2001) and Le Loc'h (2004), and the diet composition was obtained from Lobry et al. (2008). Ash-free dry weights were converted to carbon contents using a conversion factor of 0.518 (Salonen et al., 1976 in Brey 2001).

Meiofauna

272 The values of mean annual biomass of meiofauna, the $P / B$ ratio and $Q / B$ were obtained from the literature 273 (Ratsimbazafy, 1998; Chardy and Dauvin, 1992; Le Loc’h, 2004).

\subsubsection{Zooplankton}

Mean annual biomasses of zooplankton were collected from the Seine Aval I programme. $P / B$ and $P / C$ ratios were obtained from another study focused on the Eastern part of the Bay of Seine (Rybarczyk and Elkaim, 2003).

\subsubsection{Bacteria}

280 The benthic bacterial biomass, $\mathrm{P} / \mathrm{B}$, and Q/B ratios were taken from Chardy (1987), McIntyre (1978), and Mackinson and Daskalov (2007), respectively.

\subsubsection{Phytoplankton}

The phytoplankton biomass and $\mathrm{P} / \mathrm{B}$ ratio were taken from data collected in the Bay of Seine by Baehr et al. (2014) and Souissi (2007).

\subsubsection{Detritus}

The mean annual biomass of dead organic matter was obtained from a study focused on the Eastern part of the Bay of Seine (Tecchio et al., 2015).

\subsection{Balancing the Ecopath model}

To obtain a mass-balanced model, inputs (i.e. $B, P / B, Q / B, E E$, and diets) were slightly and manually modified to satisfy the constraint of Ecotrophic Efficiency lower than 1. We also checked that physiological rates were within the known limits for each functional group: (i) $P / Q$ of $0.1-0.3$ for consumers, and (ii) respiration/biomass (R/B) ratios of 1-10 for fish groups. Biomass accumulation and net migration were both set to zero. The EwE pedigree routine was used to quantify the input parameter uncertainties (Christensen 
and Walters, 2004). It helped to identify the least certain parameters that should be modified first to achieve mass balance. The balancing approach that we used was top-down, starting with the top predator groups and moving down the food web to balance inconsistencies. When modifications of the data had to be performed, diet compositions (DC) were modified first, and then ratios of $\mathrm{P} / \mathrm{B}$ and $\mathrm{Q} / \mathrm{B}$. Biomasses (B) were considered as less uncertain, and thus were modified the last during the balancing process.

Biomasses of the small pelagic fish and flatfish were left to be estimated by the model after setting their Ecotrophic Efficiency to 0.99 given their high exploitation rate. The estimated biomasses were higher than the input data first entered during model construction for those two groups. This can be partly explained by the fact that the GOV bottom-trawl deployed during the Channel Ground Fish Survey by IFREMER is not fully adapted to capture these species, the abundance of which is thus likely to be underestimated. In the same way, the deposit feeders and suprabenthos biomasses were also left to be estimated by the model assuming an Ecotrophic Efficiency to 0.99 .

\subsection{Simulating the "reef effect" due to the wind farm implantation using Ecosim simulations}

The Ecosim module was used to analyse the potential impacts of biomass accumulation on hard substrates represented by the wind turbines and the scour protections on the structure and functioning of the local trophic web during the operational phase. The dynamic routine of the EwE package, Ecosim allows to describe temporal changes of the system variables (biomass, fishing, predation) starting from the initial Ecopath model (Walters et al., 1997; Christensen and Walters, 2004). The Ecosim equation that models the biomass growth rate for each group (i) is:

$$
\frac{d B_{i}}{d t}=g_{i} \sum_{j} Q_{j i}-\sum_{j} Q_{i j}+I_{i}-\left(M_{i}+F_{i}+E_{i}\right) B_{i} \quad \text { (Eq. 4) }
$$

Where $I_{i}$ and $E_{i}$ are the immigration and emigration rates, $M_{i}$ is the natural mortality, and $F_{i}$ is the fishing mortality (Walters et al., 1997, Christensen and Walters 2004). Calculations of the consumption rates $\left(Q_{i j}\right)$ are based upon the 'foraging arena' theory, in which the biomass of $i$ is divided between available prey (vulnerable fraction, $V_{i}$ ) and unavailable prey (non-vulnerable fraction, $B_{i}-V_{i}$ ). A low value of vulnerability will indicate a 'bottom-up' controlled interaction, while a high value of vulnerability will indicate that mortality of the prey is controlled by the predator biomass, as in a 'top-down' control (Ahrens et al., 2012).

Ecosim was used to build another Ecopath solution, derived from the initial Ecopath model described above. Biomasses of species that would presumably profit from the "reef effect" such as benthic invertebrates (filter feeders, bivalves, and predators), benthos feeders fishes, whiting, pouting, Atlantic cod, other flatfish, sole 
and surface feeders seabirds, were modelled based on data from the literature (Koller et al., 2006; Reubens et al., 2011; Lindebon et al., 2011, Krone et al., 2013a; Krone et al., 2013b; Reubens et al., 2013). These changes in biomass were the main variations taken into account to drive the evolution of the system through time. Species biomasses on the turbine foundations and scour protections were calculated by multiplying the average biomass per $\mathrm{m}^{2}$ found in the literature by the surface area represented by the turbine foundations and scour protections and divided by the total wind farm area at Courseulles-sur-mer. Then, the estimated increase was added to the basal biomass for each functional group susceptible to profit from the implantation of the wind farm in 2018. Forcing time series over a period of 30 years were as such established for the biomass of the following groups: benthic invertebrates (filter feeders, bivalves, and predators), benthos feeders fish, whiting, pouting, Atlantic cod, other flatfish, sole, surface feeders seabirds. These forcing time series were responsible for a disruptive change in the biomass of the species cited above. Ecosim model were run with the new biomass values for the targeted groups listed above and the original biomass values for the other functional groups in the model. In this scenario, the biomass of groups that could presumably profit from a reef effect were simultaneously increased and vulnerability was set to 2 for all groups. In this scenario, we chose to take into account all the effects (direct and indirect), not only those directly propagating from prey-predator interactions. The biomass and production of the phytoplankton was blocked at the initial value. All other parameters and ratios remained unchanged. Then, a new Ecopath model was extracted at the end of the 30 years simulation to compare the situation before (BOWF (Before Offshore Wind Farm) model described above) and after the construction of the offshore wind farms (REEF scenario).

To test the robustness of our working hypotheses, four sensitivity analyses were also performed to analyse effects of fish and benthic aggregation on the trophic web functioning, inside an OWF. The methods included: (1) forcing biomass dynamics of only the bivalves and filters feeders compartments through time (forcing biomass); (2) starting to increase the biomass of benthic organisms and then one year later increase the biomass of fish that would presumably profit from the reef effect in order to take into account the different species time span (time lag); (3) and (4) changes in the vulnerability of the bivalve group. Vulnerability indicates the degree to which an increase in predator biomass will cause mortality for a prey (Christensen et al., 2008). In these two additional scenarios, we increased the vulnerability of bivalves to 5 and 10 respectively. These sensitivity analyses are presented in the Supplementary Material Appendix B.

\subsection{Analysing ecosystem organisation, major interactions and emergent properties}

354 For the two Ecopath models (BOWF model and REEF scenario), the trophic level of each functional group was calculated from its diet composition matrix. It is computed as the weighted average of the trophic levels of its prey, when primary producers and non-living material are set at a trophic level of 1 : 
where $D C_{j i}$ is the fraction of the prey $i$ in the diet of the predator $j$.

Ecological Network Analysis (ENA) indices were calculated using the network analysis plug-in included in EwE (Christensen and Walters, 2004). The following ENA indices were retained:

- Total System Throughflow (TST gC $\mathrm{m}^{-2}$ year-1) was calculated as the sum of the flow balance (inflow = outflow) of all compartments (Latham, 2006).

- The Total System Throughput (T.., $\left.\mathrm{gC} \mathrm{m}^{-2} \mathrm{year}^{-1}\right)$ was calculated as the sum of all the flows in the food web, characterising its overall activity and size (Latham, 2006).

- The Omnivory Index (OI) represents the trophic specialisation of the predator, assuming values close to zero when the consumer is fully specialized, feeding on a single trophic level, and higher values when the predator feeds on several trophic levels (Pauly et al., 1993).

- The System Omnivory Index (SOI) was calculated as the average of the Ols of the individual group, weighted by the logarithm of each consumer intake (Pauly et al., 1993; Christensen and Walters, 2004). It is both a measure of the predators trophic specialisation in terms of trophic levels and an indicator of the structure and complexity of a trophic network, assuming that high values of SOI correspond to a web-like structure and low values of SOI to a chain-like structure (Libralato, 2008). For instance, marine ecosystems of the northern Europe have a SOI ranging from 0.14 to 0.36 (Mackinson and Daskalov, 2007).

- The Finn's Cycling Index (FCl) gives the percentage of all flows generated by cycling (i.e. the percentage of carbon flowing in circular pathways) (Finn, 1980).

- The Ascendency (A) is a measure of the system activity (Total System Throughput) linked to its degree of organization (Average Mutual Information; AMI) (Ortiz and Wolff, 2002). This index was related to the developmental status or maturity of an ecosystem (Ulanowicz, 1986).

- The Transfer Efficiency (TE) is the fraction of total flows of each discrete trophic level that throughputs into the next one (Lindeman, 1942). The "Lindeman spine plot" is a representation of trophic transfers into a linear food chain. It includes the fraction of the biomass directed to detritus by each discrete trophic level ('flow to detritus') and the transfer efficiency from one level to the next one (TE).

The Mixed Trophic Impact (MTI) routine was applied to evaluate the impacts of direct and indirect interactions in the food web. This analysis shows the theoretical impact that a slight increase in the biomass of one group would have on the biomasses of all the other groups in the system (Ulanowicz and Puccia, 1990). 
Although this is a static analysis that does not account for temporal scale changes, the MTI can be used as a

388 sensitivity analysis to explore possible impacts of moderate biomass variations. The Keystoneness Index was 389 calculated for each functional group, to identify which groups possess a high overall effect on the other 390 groups compared to their relatively low biomass. Calculations were made according to the index defined by 391 Libralato et al. (2006). This analysis uses the MTI matrix to calculate an index summarising the impact that a 392 minimal variation of biomass of a particular group would have on the biomasses of the other groups in the 393 system. The Detritivory/Herbivory ratio $(D / H)$ is the ratio between values of detritivory flows (from detritus 394 to trophic level II) and herbivory flows (from primary producers to trophic level II) (Ulanowicz, 1992). The 395 proportion between biomass of fish groups and biomass of invertebrate groups was also calculated.

396

\section{RESULTS}

An Ecopath model (BOWF model) of the area was constructed using data from local sampling surveys or from similar ecosystems. Another Ecopath model (REEF scenario) was derived after simulating 30 years of dynamic evolution of the area following the construction of an offshore wind farm and the increase in hard substrates causing a reef effect (i.e. aggregation of biomass).

\subsection{Compartments' ecological roles before the installation of the offshore wind farm}

The overall pedigree index value calculated for the BOWF model before the implantation of the offshore wind farm was 0.523 .

The functional group dominating biomass was "bivalves" (mostly composed of the clam Polititapes rhomboides), which represented $42 \%$ of the total living biomass of the system (Table 1 ). The functional groups contributing most to total throughflows were zooplankton, bacteria, and bivalves, with contributions of $36 \%, 15 \%$, and $8 \%$, respectively.

The Trophic Level of functional groups ranged from $T L=1$ for primary producers and detritus, as imposed by construction, to a maximum of 4.8 for grey seals in the BOWF model (see Table 1 in Appendix A). Other marine mammals (i.e. bottlenose dolphins, harbour porpoises and harbour seals) ranked just below as top predators in the trophic webs. The omnivory of the functional groups, estimated by the omnivory index (OI), was low overall (0.001-0.474), except for Surface-feeding seabirds ( $\mathrm{OI}=0.757)$ (see Table 1 in Appendix A). These low values indicate a general dietary specialisation of the fauna, each functional group feeding on a narrow range of trophic levels.

The MTI analysis highlighted that benthic invertebrate predators negatively affected benthic invertebrate filter feeders, bivalves, deposit feeders, suprabenthos and meiofauna (Fig. 3). Other predators (such as sea 
418 bream or flafish), also feeding on those benthic invertebrates and thus considered as competitors, responded 419 negatively to an increase of benthic invertebrate predators' biomass. In fact, functional groups benefiting 420 from an increase in benthic organisms' biomass (predators, filter feeders and bivalves) were some fish species 421 (i.e. flat fish and sea bream), marine mammals and seabirds. Pouting exerted a widespread influence over 422 the trophic web, due to its wide diversity of prey items (benthic invertebrate deposit feeders, filters feeders, 423 and predators, pilchard, sprat, and planktivorous fish).

$<$ Figure 3>

The keystoneness index was highest for pouting (0.095) and for benthic invertebrate predators (0.059), which also presented the maximum values of relative total impact (Fig. 4; see Table 1 in Appendix A). Another group with relatively high keystoneness and low biomass was the harbor porpoise.

\section{$<$ Figure 4>}

\subsection{Ecosystem structural features after the installation of the wind farm}

Based on the simulation of the wind farm presence, REEF scenario, Ecosim generated a variation in biomass of the functional groups for which the biomass inputs were not set a priori.

An increase in substrates available for epibenthic sessile organisms and fish after the wind farm construction implied an increase of the total system biomass by $40 \%$.

First, for those functional groups for which we calculated an accumulation of biomass on new substrates, the new biomass values increased by a factor of 6 for the surface feeders seabirds (dominated by Larus sp.), 3.5 for the Atlantic cod, 4 for whiting, 2 for pouting, 2 for fish benthos feeders (dominated by Callionymus sp.), 2 for sole, 4 for other flatfish (dominated by Limanda limanda), 1.5 for benthic invertebrate predators (dominated by the omnivorous species Psammechinus miliaris), 1.5 for filter feeders (Balanus sp.), and 2 for bivalves (dominated by Mytilus edulis) (Table 1).

For groups whose biomass was not forced, the construction of the wind farm induced an increase in the biomass of top predators, except for "diving seabirds" (Table 1). The biomass of sea bream and plaice were higher in the REEF scenario than in the BOWF model (approximately 3 times higher, respectively; Table 1). 
443 In contrast, Atlantic horse mackerel, poor cod, and piscivorous fish declined strongly with a 55\%, 81\%, and $44497 \%$ diminution, respectively (Table 1). The biomass of benthic invertebrates, deposit feeders and 445 suprabenthos also decreased in the REEF scenario (with a decrease of $17 \%$ and $15 \%$ respectively). The ratio 446 of fish biomass over invertebrate biomass was reduced by approximately $34 \%$ between the two periods 447 (BOWF model/REEF scenario). This was related to the strong increase in benthic invertebrate biomass that 448 was multiplied by approximately 2 in the REEF scenario, while fish biomass was multiplied by 1.1 only. These

449 The keystoneness index varied between the two periods as biomasses changed (Fig. 4; see Table 1 in 450 Appendix A). Pouting was the functional group with the highest keystoneness index in the two scenarios. In 451 the BOWF model, benthic invertebrate predators occupied the second place followed by harbor porpoise 452 whereas in the REEF scenario, zooplankton occupied the second place and was followed by benthic 453 invertebrate predators.

The total ecosystem activity (T..), representing the sum of all flows in the system, increased between the two periods by approximately $13.96 \%$ (Table 2). The System Omnivory index (SOI) of the 2 trophic webs increased by $15.03 \%$ (from 0.173 to 0.199 ) between the two periods. This increase should be related to the variations of pouting omnivory (i.e. increased by a factor of 3). The Finn's Cycling Index (FCl) increased by $40 \%$ between the two scenarios (Table 2). This result is in line with the increase of detritivory (mainly due to benthic invertebrate predators and filter feeders), which doubled. The ascendency (A) increased by 15\% (Table 2). The transfer efficiencies (TE) showed a similar pattern in between the two periods, decreasing with TL in the 2 models (Fig. 5). However, values were slightly lower in the REEF scenario.

\section{$<$ Figure 5>}

The comparison of compartment throughflows before and after the construction of the offshore wind farm showed that activity of top predators, except for "diving seabirds", increased after the construction. The compartments sharks and rays, Atlantic cod, whiting, pouting, European sprat and sea bream strongly increased their activity after the construction as well (Fig.6 ). A similar pattern was observed with all flat fish groups (i.e. sole, plaice, and other flatfish). Activity strongly increased after the construction in some benthic groups, namely invertebrate predators, filter feeders and bivales. In contrast, other benthic groups such as king scallop, deposit feeders and suprabenthos, reduced their overall activity once the offshore wind farm was built. 
The system overall EE (the percentage of production consumed by predators including fishing activities) increased by $5 \%$ between the two periods. For instance, the phytoplankton biomass and $\mathrm{P} / \mathrm{B}$ remained unchanged in the REEF scenario but its EE increased by $32 \%$. The biomasses and consumptions exerted by bivalves and benthic invertebrates filter feeders were higher in the REEF scenario than in the BOWF model; consuming/grazing more phytoplankton (e.g. until 4 times higher for filter feeders; Table 1). The EE of these species were also higher in the REEF scenario due to the fact that they were more consumed by fish such as cod, pouting and sea bream. The EE of these fish species were also higher as they were more consumed by marine mammals. For instance, Atlantic cod was consumed approximately 5 and 3.5 times more by cetaceans and seals, respectively, after the wind farm implantation. Again, after the construction, the consumption of detritus in the system increased by $68.5 \%$.

In terms of flow analysis, the detritivory/herbivory ratio $(\mathrm{D} / \mathrm{H})$ increased by $18.8 \%$ between the two periods. The detritivory was multiplied by 1.5 and the herbivory was multiplied by 1.2 between the two situations.

\subsection{Sensitivity analyses}

The results of the four scenarios (presented in the Supplementary material, Appendix B) highlight that the choices made in the "REEF" scenario were robust as they show that even considering a possible range of variability, we obtained the same main results.

For instance, for groups without forced biomass at the start of the simulation, the construction of the wind farm induced an increase in biomass, especially for top predators, in the four additional scenarios (Table 1, in Supplementary Material, Appendix B). For instance, the biomass of sea bream after 30 years of simulations were higher in the four scenarios than in the "BOWF" Ecopath model (approximately 3 times higher in the "REEF Filter Feeders" and "time lag" scenarios and approximately 4 times higher in the "REEF Bivalve V5" and "V10" (Table 1, in Supplementary material, Appendix B)). On the same line, the biomass of plaice was higher in the four scenarios compared to the BOWF Ecopath model (approximately 3 times higher). This generalized increase in apex predators was congruent with the one highlighted under the "REEF" scenario. However, in the "REEF Filter feeders", the biomass of predatory fish (cod, whiting) resulting from this simulation increased, but this increase was inferior to the input that we originally entered for the "REEF scenario". The difference can be explained because EwE takes into account only prey-predator interactions and does not take into account other indirect effects such as the reserve effect that exist in the park where biomass sampling was performed.

In terms of flow analysis, we observed an increase in the Detritivory/Herbivory ratio $(D / H)$ between the BOWF model and the different scenarios (Table 2, in Supplementary Material, Appendix B). For instance, the D/H 
503

504

505

506

507

508

509

510

511

512

513

514

515

516

517

518

519

520

increased by $11 \%, 17 \%, 20 \%$ in the "REEF filter feeders", "REEF time lag", "Reef mussel V5", "Reef mussel V10", respectively (Table 2, in Supplementary Material, Appendix B). Other ENA indices remained mostly unchanged under the different scenarios. Again, this change in $\mathrm{D} / \mathrm{H}$ was in accordance with the conclusion drawn from the "Standard REEF" scenario.

\section{Discussion}

\subsection{Food web control before the installation of the offshore wind farm}

From a methodological point of view, the high value of the pedigree index indicated that the input data used in the reference Ecopath model (BOWF model) were of good quality when compared to the distribution of pedigree values for pre-existing models (Morissette, 2007). In fact, the pedigree index (0.523) was in the highest part of the range (0.164 to 0.676) reported in Morissette (2007). Indeed, biomass data were mainly obtained from local, highly replicated, and detailed samplings and the diet compositions of the main fish species came from stomach content studies performed in the eastern English Channel.

The Courseulles-sur-mer food web appeared to be mostly controlled by intermediate trophic levels. First, the MTI analysis revealed that benthic invertebrate predators and pouting, which occupied an intermediate trophic level ( $T L=3$ and $T L=3.7$ respectively), had a strong impact on numerous groups of both higher and lower trophic levels in the system. For instance, pouting supported a high diversity of predators (i.e. marine mammals, cephalopods, elasmobranch and teleosts) and fed mainly on benthic invertebrate predators (i.e. crustaceans), filter feeders, and suprabenthos. This result concurred with the high ranking of pouting in the keystoneness index (classification see Table 1 in Appendix A). A keystone group is defined as a group having a high structuring impact on the other groups, despite a relatively low biomass (Power et al., 1996). Since pouting biomass was high (i.e. $3.85 \mathrm{gC} \mathrm{m}^{-2}$ year-1), this group was likely to be a key structuring group in the system rather than a keystone group sensu Power et al. (1996). These results suggest a possible "wasp-waist" control of the system by intermediate trophic levels (Cury et al., 2000). In "wasp-waist" systems, the flow of energy is controlled by the mid-trophic levels rather than the bottom or top organisms. The mid-trophic levels exert top-down control on zooplankton and benthic groups, and bottom-up control on top predators (Cury et al., 2000). This type of control has generally been demonstrated to be the norm for small plankton-feeding pelagic species, such as anchovies and sardines, in upwelling pelagic ecosystems around the world (Cury et al., 2000, 2004; Coll et al 2006; Bakun, 2006). The role played here by pouting, a demersal species, was hence an original feature of the Courseulles-sur-mer food web. Pouting could then be considered as a benthic equivalent of sardines but with a higher position in the food web compared to examples involving small pelagics. However, these results are only based on the MTI and Keystoneness analysis that are interrelated and must be taken with caution. 
4.2 Potential impacts of the reef effect inside the offshore wind farm on the trophic web functioning

537 As the results show that even considering a possible range of variability through the 4 variants of the "REEF" 538 scenario, we obtained the same main results, we choose to discuss only the results of the "REEF" scenario 539 (Supplementary Material, Appendix B).

540 The construction of the Courseulles-sur-mer offshore wind farm was suspected to increase detritivory in the 541 food web. As expected, the $\mathrm{D} / \mathrm{H}$ ratio changed positively between the two periods, underlying the importance 542 of the trophic interactions involved in the detrital chain (Dame and Christian, 2007). This was related to the 543 higher consumption of detritus by benthic organisms and might confirm the hypothesis of Norling and 544 Kautsky $(2007,2008)$ by which blue mussels expansion could be responsible for a shift from primary producers and grazers dominated food chains towards a more detritus-feeding community. Sessile organisms, such as blue mussels colonizing the 75 turbines, are indeed expected to enhance the benthic production of food for fish and benthic organisms through the deposition of organic matter such as feces and dead organisms (Wilhemsson et al., 2006; Maar et al., 2009). Wind turbines and scour protections were identified as offering particularly favorable substrates and feeding conditions for blue mussels in field studies (Wilhelmsson, et al., 2006; Wilhelmsson and Malm, 2008; Maar et al., 2009; Krone et al., 2013). Bivalves can form dense belts and, in some cases, account for almost $97 \%$ of the total epibenthic biomass on foundations (Maar et al., 2009). According to Maar et al. (2009), wind turbines can support a mussel biomass ten times higher per unit area than the one observed on bridge pillings in the same region, and the growth of blue mussels on turbines can also double the biomass of filter feeders in a wind farm area as a whole compared to the situation before its construction. Another potential effect suggested in the litterature is an input of organic material from fish and crustaceans closely associated with the turbines as well as an entrapment of organic material by the turbines themselves, contributing to an enrichment of the seabed and enhancing the abundance of deposit-feeding organisms and their predators (Maar et al., 2009; Wilhelmsson et al., 2010). This material provided an additional source of food but, more importantly, a different "food quality" (Koller et al., 2006). In soft bottom communities, filters and detritus feeders feed on small particulate matter deposited on the seabed (Koller et al., 2006). Koller et al. (2006) stated that this different quality of food coming from the wind turbines was responsible for a "shortcut within the food web" because this resource was consumed by larger predators and scavengers. Other effects suggested in the literature, but that could not be demonstrated here as our flows were only in carbon currency, are that the increase in filter feeders biomass, and more particularly in blue mussels, could imply an increased excretion of ammonium and thus a clearer water (reduction of water turbidity), which in turn could lead to an increase in growth rates of phytoplankton and filamentous algae (Kautsky and Evans, 1987; Prins and Smaal, 1994; Norling and Kautsky, 2008).

The introduction of turbines with their associated scour protections generated an additional source of food in the ecosystem. Habitats created by the monopile foundations and the fauna they harbour were 
responsible for an increase in the system total biomass. Possibly due to the biomass modifications, EE values 572 (the percentage of production consumed by predators) of the whole ecosystem showed an increase of $5 \%$. 573 This result can be explained by the increase in predation exerted by the species attracted by the reef effect. 574 For instance, our model showed that the benthic invertebrates colonising the monopile foundations served 575 in turn as food resources for other species such as poutings and sea breams. The related increases in pouting, 576 cod and sea bream biomass was in fine beneficial to their predators, notably marine mammals. These results confirm the hypothesis enounced in the introduction of this study that the benthic biomass increase acts as an additional prey resource for higher trophic levels up to apex predators (Lindeboom et al., 2011; Scheidat et al., 2011; Russell et al., 2014). This result was also in line with the stomach content analyses of Reubens et al. (2011), who demonstrated that pouting fed on the macrobenthos produced on the Thornton bank wind 581 turbines in the Belgian part of the North Sea. For instance, the amphipode, Jassa herdmani, presented a 582 numerical abundance index of $84.6 \%$ and it was the most important prey species of the pouting dietary 583 composition (Reubens et al., 2011). Moreover, it could be assumed that seabirds strongly profit from 584 additional biomass of epifaunal bivalves on the 75 turbines as they would become easily available. These 585 basic parameters estimates analysis was to some point consistent with the relatively low values of SOI 586 indicating a chain-like structure both before and after the installation of the offshore wind farm.

According to our model, the "reef effect" generated by the construction of the Courseulles-sur-mer offshore 588 wind farm was predicted to have a relatively limited impact on the structure and flow pattern of the local food web. The comparison of the ENA indices (total ecosystem activity (T..), system omnivory index (SOI), ascendency ( $A$ ) and keystoneness) between the BOWF model and the REEF scenario showed small variations between the two periods. Furthermore, the transfer efficiencies (TE) decreased parallely with TL in the 2 models indicating that the compartments, although exposed to an increase in biomass of some specific groups, behaved functionally in a similar way under the two scenarios. Ecopath is a single solution model and so direct statistical comparisons were not possible. As network indices of Ascendency are scaled according to log values of combinations of flows, small changes expressed in percentages could reflect much larger disparities, and hence larger ecological changes (Ulanowicz 1986; Baird \& Ulanowicz 1993). In addition, the ENA results from the BOWF model and the REEF scenario can be compared with other ecosystems studied with the same methodology (Ecopath) and located in the same biome such as the Bay of Somme (Rybarczyck et al., 2003), the Dublin Bay (Wilson and Parkes, 1998), and the Seine Estuary (Tecchio et al., 2015). Values of ENA indices in both situations for the Courseulles-sur-mer area remained in the range delimited by these similar ecosystems, suggesting no major trophic structural and functional shift due to the installation of an offshore wind farm (Table 2). 


\subsection{Advantages and limitations of the EwE models}

Conceptually, the main asset of this study was to lay the foundations defining an ecosystem-based approach to marine renewable energy management, in line with what has been done during the last 20 years in the Ecosystem Approach to Fisheries (Garcia et al., 2003). Previous studies have largely focused on the conservation of some groups of valuable species and their habitats only. The proposed model considered the full range of size classes of biota, from prokaryotes to apex predators, for a representative site of the eastern Bay of Seine basin: the Courseulles-sur-mer offshore future wind farm. The approach for this specific site can then be transposed to other wind farm projects in the English Channel and broadly to other shallow and macrotidal seas of temperate latitudes. Applying this modelling method can enrich the field of environmental impact studies on future offshore wind farms and, more generally, on marine renewable energy sites.

Models for offshore wind farms are by definition atypical due to their intrinsic small spatial scale (here, 50 $\mathrm{km}^{2}$ ) with one on the main drawbacks being the fact that the population dynamics and home range of mobile species vastly exceed the limits of wind farm sites. Here, as a partial solution, we considered trophic transfers outside the area of the Courseulles-sur-mer offshore wind farm for marine mammals and seabirds by setting imports in the diet composition matrix. This limitation is common to all Ecopath small-scale models (e.g. marine protected areas (Albouy et al., 2010; Colléter et al., 2012; Valls et al., 2012). Regarding community changes, our choice here was to use estimates derived from the literature and expert knowledge and not from complex models. This option was relevant here as a lot of information coming from the offshore wind farms already in exploitation could be extracted and helped formulating meaningful hypotheses. Another possibility would have been to use these data for calibrating a community model predicting the changes in existing species and at the same time the arrival of new species around the turbines. Finally, the BOWF model and REEF scenario could not simulate all possible impacts generated by the increased biomass of mussels on biogeochemical process such as the excretion of ammonium as our model is based only on carbon flows.

\section{Conclusions}

This ecosystem-based approach of offshore wind farm impacts showed 1) an original control of the Courseulles-sur-mer site food web by pouting at the intermediate trophic levels, indicating a potentially "wasp-waist" controlled food web, 2) that the anticipated increase of mussel biomass after the offshore wind farm construction is predicted to lead to a food web dominated by detritivory, as hypothesized by Norling and Kautsky (2008), and (3) that the anticipated increase in benthic invertebrate and benthos feeding fish biomass, in response to the reef effect, is predicted to attract and benefit to apex predators, as hypothesized by Lindeboom et al. (2011) and Henkel et al. (2014).

By combining the data collected on various ecosystem components, we determine in this study how the local food web structure and function may change 30 years after the installation of the offshore wind farm. The 
637 Ecopath models built in this study can then be useful to interpret how other threats, such as climate change 638 or restrictions of fisheries activities within the offshore wind farm limits, can further affect the trophic web 639 structure and functioning. This study could be considered as a first step in using food web models to assess 640 offshore wind farm impacts on the whole ecosystem.

\section{ACKNOWLEDGEMENTS}

642 This work was co-funded by the Normandy Region and by the group "Eoliennes Offshore du Calvados" (EOC). 643 We also acknowledge, for their help in compiling the datasets and for giving expert advices: Georges Safi 644 and Jean-Paul Robin (UMR BOREA, Caen), Alexandrine Baffreau, Sandric Lesourd and Maxime Navon (UMR 645 M2C, Caen), Ludivine Martinez, Jérôme Spitz and Charlotte Lambert (Observatoire PELAGIS, La Rochelle), 646 Francis Gohin and Maria Ching Villanueva (IFREMER, Brest), Gregory Certain (Université de Suède des 647 Sciences de l'Agriculture, Uppsala), James Jean Baptiste (Groupe Ornithologique Normand, Caen) and Nicolas 648 Bacq (Groupement d'Intérêt Public "Seine-Aval"). This work was an introduction to the project Trophik 649 (ANR/FEM EMR-ITE 2015).

650 
Ahrens, R.N.M., Walters, C.J., Christensen, V., 2012. Foraging arena theory. Fish Fish. 13, 41-59. doi:10.1111/j.1467-2979.2011.00432.x

Albouy C., Mouillot D., Rocklin D., Culioli J.-M. \& Le Loc'h F. 2010. Simulation of the combined effects of artisanal and recreational fisheries on a Mediterranean MPA ecosystem using a trophic model. Mar. Ecol. Prog. Ser. 412: 207-221

Andersson, M.H., Öhman, M.C., 2010. Fish and sessile assemblages associated with wind-turbine constructions in the Baltic Sea. Mar. Freshw. Res. 61, 642-650. doi:10.1071/MF09117

Baehr, A., Menet-nedelec, F., Riou, P., Fontaine, B., Francoise, S., Gangnery, A., Jacqueline, F., Lamort, L., Lesaulnier, N., Maheux, F., Picoche, C., Pierre-duplessix, O., Rabiller, E., Simon, B., 2014. Réseau Hydrologique Littoral Normand (RHLN) - Suivi 2012. Ifremer. pp.212

Bailey, H., Brookes, K.L., Thompson, P.M., 2014. Assessing environmental impacts of offshore wind farms : lessons learned and recommendations for the future. Aquat. Biosyst. 10, 1-13. doi:10.1186/2046-906310-8

Baird, D., Ulanowicz, R.E., 1993. Comparative study on the trophic structure, cycling and ecosystem properties of four tidal estuaries. Mar. Ecol. Prog. Ser. 99, 221-237.

Baird, D., Christian, R.R., Peterson, C.H., Johnson, G. a., 2004. Consequences of hypoxia on estuarine ecosystem function: Energy diversion from consumers to microbes. Ecol. Appl. 14, 805-822. doi:10.1890/02-5094

Bakun, A., 2006. Wasp-waist populations and marine ecosystem dynamics: Navigating the "predator pit" topographies. Prog. Oceanogr. 68, 271-288. doi:10.1016/j.pocean.2006.02.004

Bergström, L., Kautsky, L., Malm, T., Ohlsson, H., Wahlberg, M., Rosenberg, R., Capetillo, N.Å., 2012. The effects of wind power on marine life on marine life - A synthesis. REPORT 6512 October 2012.

Bergström, L., Sundqvist, F., Bergström, U., 2013. Effects of an offshore wind farm on temporal and spatial patterns in the demersal fish community. Mar. Ecol. Prog. Ser. 485, 199-210. doi:10.3354/meps10344

Boehlert, G.W., Gill, A.B., 2010. Environmental and ecological effects of ocean renewable energy development: a current synthesis. Oceanography 23, 68-81. oi:http://dx.doi.org/10.5670/oceanog.2010.46

Boyd, I.A., 2002. Energetics: consequences for fitness. In: Hoelzel, A.R. (Ed.), Marine Mammal Biology an Evolutionary Approach. Blackwell Science, pp.247-278.

Bradford-Grieve, J.M., Probert, P.K., Nodder, S.D., Thompson, D., Hall, J., Hanchet, S., Boyd, P., Zeldis, J., Baker, A.N., Best, H. a., Broekhuizen, N., Childerhouse, S., Clark, M., Hadfield, M., Safi, K., Wilkinson, I., 2003. Pilot trophic model for subantarctic water over the Southern Plateau, New Zealand: A low biomass, high transfer efficiency system. J. Exp. Mar. Biol. Ecol. 289, 223-262. doi:10.1016/\$00220981(03)00045-5

Brey, T., Müller-Wiegmann, C., Zittier, Z.M.C., Hagen, W., 2010. Body composition in aquatic organisms - A global data bank of relationships between mass, elemental composition and energy content. J. Sea Res. 64, 334-340. doi:10.1016/j.seares.2010.05.002

Brey, T., 2001. Population Dynamics in Benthic Invertebrates. A Virtual Handbook. http://thomasbrey.de/science/virtualhandbook.

Brunel, P., Besner, M., Messier, D., Poirier, L., Granger, D., Weinstein, M., 1978. Le traîneau suprabenthique MACER-GIROQ : appareil amélioré pour l'échantillonnage quantitatif étagé de la petite faune nageuse au voisinage du fond. Int. Revue. Hydrobiol. 63, 815-829.

Cachera, M. 2013. mplications of morphological and functional traits for trophic relationships within fish communities and marine trophic network architecture. Thèse de doctorat de l'Université Sciences et Technologies de Lille, France. pp 247.

Chaalali, A., Saint-Béat, B., Lassalle, G., Le Loc'h, F., Tecchio, S., Safi, G., Savenkoff, C., Lobry, J., Niquil, N., 2015. A new modeling approach to define marine ecosystems food-web status with uncertainty assessment. Prog. Oceanogr. 135, 37-47. doi:10.1016/j.pocean.2015.03.012

Chardy, P., 1987. Modèle de simulation du système benthique des sédiments grossiers du golfe normandbreton (Manche). Oceanol. Acta. 10, 421-434.

Chardy, P., Dauvin, J.C., 1992. Carbon flows in a subtidal fine sand community from the western English Channel: a simulation analysis. Mar. Ecol. Prog. Ser. 81, 147-161. 
Christensen, V., Walters, C.J., 2004. Ecopath with Ecosim: methods, capabilities and limitations. Ecol. Modell. 172, 109-139. doi:10.1016/j.ecolmodel.2003.09.003

Christensen, V., Walters, C.J., Pauly, D., 2005. Ecopath with Ecosim: A User's Guide. Fisheries Centre. University of British Columbia, Vancouver, Canada, pp. 154.

Christensen, V., Walters, C.J., Pauly, D., Forrest, R., 2008. Ecopath with Ecosim version 6 User Guide. Lensfest Ocean Futures Project 2008 1-235.

Christensen, V., Walters, C.J., Ahrens, R., Alder, J., Buszowski, J., Christensen, L.B., Cheung, W.W.L., Dunne, J., Froese, R., Karpouzi, V., Kaschner, K., Kearney, K., Lai, S., Lam, V., Palomares, M.L.D., Peters-Mason, A., Piroddi, C., Sarmiento, J.L., Steenbeek, Sumaila, R., Watson, R., Zeller, D., Pauly, D., 2009. Databasedriven models of the world's large marine ecosystems. Ecol. Model. 220, 1984-1996.

Coll, M., Palomera, I., Tudela, S., Sardà, F., 2006. Trophic flows, ecosystem structure and fishing impacts in the South Catalan Sea, Northwestern Mediterranean. J. Mar. Syst. 59, 63-96. doi:10.1016/j.jmarsys.2005.09.001

Colléter, M.,Gascuel, D.,Ecoutin, J.-M.,Tito de Morais, L., 2012. Modelling trophic flows in ecosystems to assess the efficiency of marine protected area (MPA), a case study on the coast of Sénégal. Ecol. Model. $232,1-13$

Cury, P., 2000. Small pelagics in upwelling systems: patterns of interaction and structural changes in "waspwaist" ecosystems. ICES J. Mar. Sci. 57, 603-618. doi:10.1006/jmsc.2000.0712

Daly, H.I., Pierce, G.J., Santos, M.B., Royer, J., Cho, S.K., Stowasser, G., Robin, J.P., Henderson, S.M., 2001. Cephalopod consumption by trawl caught fish in Scottish and English Channel waters. Fish. Res. 52, 5164. doi:10.1016/S0165-7836(01)00230-2

Dame, J.K., Christian, R.R., 2007. A Statistical Test of Network Analysis: Can it Detect Differences in Food Web Properties? Ecosystems 10, 906-923. doi:10.1007/s10021-007-9068-1

Dauvin, J.C., Lozachmeur, O., Capetc, Y., Dubrulle, J.B., Ghezalic, M., Mesnard, A.H., 2004. Legal tools for preserving France's natural heritage through integrated coastal zone management. Ocean Coast. Mgmt. 47, 463-477.

Dauvin, J.C., Ruellet, T., Desroy, N., Janson, A.L., 2007. The ecological quality status of the Bay of Seine and the Seine estuary: Use of biotic indices. Mar. Pollut. Bull. 55, 241-257. doi:10.1016/j.marpolbul.2006.04.010

Dauvin, J.C., Ruellet, T., 2008. Macrozoobenthic biomass in the Bay of Seine (eastern English Channel). J. Sea. Res. 59, 320-326. doi:10.1016/j.seares.2008.02.003

Dauvin, J.C., 2015. History of benthic research in the English Channel: from general patterns of communities to habitat mosaic description. J. Sea. Res. 100, 32-45.Degraer, S., Brabant, R., Rumes, B., 2013. Environmental impacts of offshore wind farms in the Belgian part of the North Sea: Learning from the past to optimise future monitoring programmes. Royal Belgian Institute of Natural Sciences (RBINS), Operational Directorate Natural Environment, Marine Ecology and Management Section: Brussels. ISBN 978-90-9027 pp. 928-2. 239.

De Mesel, I., Kerckhof, F., Norro, A., Rumes, B., Degraer, S., 2015. Succession and seasonal dynamics of the epifauna community on offshore wind farm foundations and their role as stepping stones for nonindigenous species. Hydrobiologia 756, 37-50. doi:10.1007/s10750-014-2157-1

De Pierrepont, J.F., Dubois, B., Desormonts, S., Santos, M.B., Robin, J.P., 2005. Stomach contents of English Channel cetaceans stranded on the coast of Normandy. J. Mar. Biol. Assoc. UK 85, 1539. doi:10.1017/S0025315405012762

Fath, B.D., Patten, B.C., 1999. Quantifying resource homogenization using network flow analysis. Ecol. Model. 123, 193-205.

Finn, J.T. 1980. Flow analysis of models of the Hubbard Brook ecosystem. Ecology 61: 562-571.

Garcia, S.M.M., Zerbi, A., Aliaume, C., Do Chi, T., Lasserre, G., 2003. The ecosystem approach to fisheries. FAO Fish.Tech. Pap. 443, 71. doi:10.1111/j.1467-2979.2010.00358.x

Garcia, C., Chardy, P., Dewarumez, J.M., Dauvin, J.C., 2011. Assessment of benthic ecosystem functioning through trophic web modelling: the example of the eastern basin of the English Channel and the Southern Bight of the North Sea. Mar Ecol 32 (Suppl. 1), 72-86

Gentil, F.,Cabioch, L., 1997. Carte des peuplements macrobenthiques de la Baie de Seine et Manche centrale sud. Carte et notice explicative de la carte. Editions de la station Biologique de Roscoff. pp. 18. 
Goberville, E., Beaugrand, G., Sautour, B., Treguer, P., Somlit team, 2010. Climate driven changes in coastal marine systems of Western Europe. Mar. Ecol. Prog. Ser. 408, 129-147.

Henkel, S.K., Suryan, R.M., Lagerquist, B.A., 2014. Marine Renewable Energy and Environmental Interactions: Baseline Assessments of Seabirds, Marine Mammals, Sea Turtles and Benthic Communities on the Oregon Shelf. In Shields, M.A., Payne, A.I.L. Marine renewable energy technology and environmental interactions, Humanity and the Sea. Springer Sciences. pp. 176.

Heymans, J.J., Guénette, S., Christensen, V., 2007. Evaluating network analysis indicators of ecosystem status in the Gulf of Alaska. Ecosystems 10, 488-502. doi:10.1007/s10021-007-9034-y

Hunt, G.L., Drew, G.S., Jahncke, J., Piatt, J.F., 2003. Prey consumption and energy transfer by marine birds in the Gulf of Alaska. Deep. Res. Part li-Topical Stud. Oceanogr. 52, 781-797. doi:10.1016/j.dsr2.2004.12.024

IPCC, 2014. Climate Change 2014: Synthesis Report. Contribution of Working Groups I, II and III to the Fifth Assessment Report of the Intergovernmental Panel on Climate Change [Core Writing Team, R.K. Pachauri and L.A. Meyer (eds.)]. IPCC, Geneva, Switzerland, pp. 151.

Kautsky, N., Evans, S., 1987. circulation of matter and nutrients in a Baltic. Mar. Ecol. Prog. Ser. 38, 201-212.

Kerckhof, F., Rumes, B., Jacques, T.J., Degraer, S., Norro, S. 2010. Early development of the subtidal marine biofouling on a concrete offshore windmill foundation on the Thornton Bank (Southern North Sea): first monitoring results. J. Underw. Technol. 29: 137-149. doi:10.3723/ut.29.137

Köller, J., Köppel, J., Peters, W., 2006. Offshore Wind Energy Research on Environmental Impacts. SpringerVerlag Berlin Heidelberg. pp.371.

Krone, R., Gutow, L., Brey, T., Dannheim, J., Schröder, A., 2013a. Mobile demersal megafauna at artificial structures in the German Bight - Likely effects of offshore wind farm development. Estuar. Coast. Shelf Sci. 125, 1-9. doi:10.1016/j.ecss.2013.03.012

Krone, R., Gutow, L., Joschko, T.J., Schröder, A., 2013b. Epifauna dynamics at an offshore foundation Implications of future wind power farming in the North Sea. Mar. Environ. Res. 85, 1-12. doi:10.1016/j.marenvres.2012.12.004

Langhamer, O., 2012. Artificial Reef Effect in relation to Offshore Renewable Energy Conversion: State of the Art. Sci. World J. 2012, 8. doi:10.1100/2012/386713

Lassalle, G., Lobry, J., Le Loc'h, F., Bustamante, P., Certain, G., Delmas, D., Dupuy, C., Hily, C., Labry, C., Le Pape, O., Marquis, E., Petitgas, P., Pusineri, C., Ridoux, V., Spitz, J., Niquil, N., 2011. Lower trophic levels and detrital biomass control the Bay of Biscay continental shelf food web: Implications for ecosystem management. Prog. Oceanogr. 91, 561-575. doi:10.1016/j.pocean.2011.09.002

Latham, L.G., 2006. Network flow analysis algorithms. Ecol. Model. 192, 586-600.

Leitão, F., 2013. Artificial Reefs: From Ecological Processes To Fishing Enhancement Tools. Brazilian J. Oceanogr. 61, 77-81. doi:10.1590/S1679-87592013000100009

Le Loc'h, F., 2004. Structure, fonctionnement, évolution des communautés benthiques des fonds meubles exploités du plateau continental Nord Gascogne. Thèse de Doctorat, Université de Bretagne Occidentale, Océanographie Biologique, Brest, France. pp. 379.

Leonhard, S., Stenberg, C., Støttrup, J., 2011. Effect of the Horns Rev 1 Offshore Wind Farm on Fish Communities Follow-up Seven Years after Construction. DTU Aqua Rep. pp. 99.

Libralato, S., 2008. System Omnivory Index. Ecol. Indic. 4, 3472-3477.

Libralato, S., Christensen, V., Pauly, D., 2006. A method for identifying keystone species in food web models. Ecol. Modell. 195, 153-171. doi:10.1016/j.ecolmodel.2005.11.029

Lindeboom, H.J., Kouwenhoven, H.J., Bergman, M.J.N., Bouma, S., Brasseur, S., Daan, R., Fijn, R.C., de Haan, D., Dirksen, S., van Hal, R., Hille Ris Lambers, R., ter Hofstede, R., Krijgsveld, K.L., Leopold, M., Scheidat, M., 2011. Short-term ecological effects of an offshore wind farm in the Dutch coastal zone; a compilation. Environ. Res. Lett. 6, 035101. doi:10.1088/1748-9326/6/3/035101

Lindeman, R.L., 1942. The trophic dynamics aspect of ecology. Ecology 23, 399-418. doi:10.1017/CBO9781107415324.004

Lobry, J., David, V., Pasquaud, S., Lepage, M., Sautour, B., Rochard, E., 2008. Diversity and stability of an estuarine trophic network. Mar. Ecol. Prog. Ser. 358, 13-25. doi:10.3354/meps07294

Love, M.S., Hyland, J., Ebeling, A., Herrlinger, T., Brooks, A., Imamura, E., 1994. A Pilot Study of the Distribution and Abundances of Rockfishes in Relation to Natural Environmental Factors and an 
Offshore Oil and Gas Production Platform off the Coast of Southern California. Bull. Mar. Sci. 55, 10621085.

Love, M.S., Caselle, J., Snook, L., 1999., Fish assemblages on mussel mounds surrounding seven oil platforms in the Santa Barbara Channel and Santa Maria Basin. Bull. Mar. Sci. 65, 497-513.

Maar, M., Bolding, K., Petersen, J.K., Hansen, J.L.S., Timmermann, K., 2009. Local effects of blue mussels around turbine foundations in an ecosystem model of Nysted off-shore wind farm, Denmark. J. Sea Res. 62, 159-174. doi:10.1016/j.seares.2009.01.008

McIntyre, A.D., 1978. The benthos of the western North Sea.Rapp. P.-v. Réun. Cons. Int. Explor. Mer 172, 405-417.

Mackinson, S., Daskalov, G., 2007. An ecosystem model of the North Sea to support an ecosystem approach to fisheries management: description and parameterisation. Sci. Ser. Tech. Rep. CEFAS 142.

MEDDE. 2012. Energies Marines renouvelables, etudes méthodolologique des impacts environnementaux et socio-économiques. pp. 357.

Martinez, L., Falchetto, H., Pettex, E., Vincent, C., Peltier, H., Ridoux, V., 2014. Etude des mammifères marins dans le cadre du parc éolien en mer du Calvados: Analyse des données existantes, synthèse bibliographique et préconisations de suivi 122 .

Morel, 2013. Bilan et actualisation des études ornithologiques menées entre 2008 et 2010 par le Groupe ornithologique normand. Projet de parc éolien en mer au large de Courseulles-sur-mer ( Calvados ). pp. 44.

Morissette, L., 2007. Complexity, Cost and Quality of Ecosystem Models and Their Impact on Resilience: A Comparative Analysis, with Emphasis on Marine Mammals and the Gulf of St. Laurence Zoology. University of British Columbia, Vancouver BC, Canada.

Mueller-Blenkle, C., McGregor, P.K., Gill, A.B., Andersson, M.H., Metcalfe, J., Bendall, V., Sigray, P., Wood, D.T., Thomsen, F., 2010. Effects of Pile-driving Noise on the Behaviour of Marine Fish. COWRIE Ref: Fish 06-08.

Nelson, B., 1979. Seabirds: their Biology and Ecology. A\&W Publishers Inc., NewYork USA.

Nilsson, S.G., Nilsson, I.., 1976. Numbers, food consumption, and fish predation by birds in Lake Möckeln, Southern Sweden. Ornis Scand. 7, 61-70.

Niquil, N., Chaumillon, E., Johnson, G. a., Bertin, X., Grami, B., David, V., Bacher, C., Asmus, H., Baird, D., Asmus, R., 2012. The effect of physical drivers on ecosystem indices derived from ecological network analysis: Comparison across estuarine ecosystems. Estuar. Coast. Shelf Sci. 108, 132-143. doi:10.1016/j.ecss.2011.12.031

Niquil, N., Baeta, A., Marques, J.C., Chaalali, A., Lobry, J., Patrício, J., 2014. Reaction of an estuarine food web to disturbance: Lindeman's perspective. Mar Ecol Prog Ser. 512, 141-154.

Norling, P., Kautsky, N., 2007. Structural and functional effects of Mytilus edulis on diversity of associated species and ecosystem functioning. Mar. Ecol. Prog. Ser. 351, 163-175.

Norling, P., Kautsky, N., 2008. Patches of the mussel Mytilus sp. are islands of high biodiversity in subtidal sediment habitats in the Baltic Sea. Aquat. Biol. 4, 75-87. doi:10.3354/ab00096

Oguz, T., Salihoglu, B., Fach, B., 2008. A coupled plankton-anchovy population dynamics model assessing nonlinear controls of anchovy and gelatinous biomass in the Black Sea. Mar. Ecol. Prog. Ser. 369, 229256. doi:10.3354/meps07540

Ortiz, M., Wolff, M., 2002. Trophic models of four benthic communities in Tongoy Bay (Chile): comparative analysis and preliminary assessment of management strategies. J. Exp. Mar. Bio. Ecol. 268, 205-235. doi:10.1016/S0022-0981(01)00385-9

OSPAR, 2008. Background document on potential problems associated with power cables other than those for oil and gas activities. OSPAR commission. pp. 50.

Patrício, J., Ulanowicz, R., Pardal, M. a., Marques, J.C., 2006. Ascendency as ecological indicator for environmental quality assessment at the ecosystem level: A case study. Hydrobiologia 555, 19-30. doi:10.1007/s10750-005-1102-8

Pauly, D., Soriano-Bartz, M., Palomares, M.L., 1993. Improved construction, parameterization and interpretation of steady-state ecosystem models. In: Christensen, V., Pauly, D. (Eds.), Trophic Models of Aquatic Ecosystems. ICLARM Conf. Proc. 26, 1-13.

Pearce, B., Fariñas-Franco, J.M., Wilson, C., Pitts, J., De Burg Z., Somerfield, P.J., 2014. Repeated mapping of 
reefs constructed by Sabellaria spinulosa Leuckart 1849 at an offshore wind farm site. Cont. Shelf Res. 83,3 13.

Petersen, J.K., Malm, T., 2006. Offshore windmill farms: threats to or possibilities for the marine environment. Ambio. 35, 75-80.

Polovina, J.J., 1984. Model of a coral reef ecosystem. I. The ECOPATH model and its application to French Frigate Shoals. Coral Reefs. 3, 1-11.

Power, Mary E., Tilman, David., Estes, James A., Menge, Bruce A., Bond, William J., Mills, Scott., Daily, Gretchen., Castilla, Juan Carlos., Lubchenco, Jane., Paine, R.T., 1996. Challenges in the Quest For Keystone. Bioscience 46, 609-620.

Prins, T.C., Smaal, A.C., 1994. The role of the blue mussel Mytilus edulis in the cycling of nutrients in the Oosterschelde estuary (The Netherlands). Hydrobiologia 282, 413-429.

Ratsimbazafy, R. A. (1998). Spectres de taille des peuplements benthiques de sables grossiers de la Manche. Thèse de doctorat, Sciences biologiques et fondamentales appliquées. Psychologies. Paris, Muséum National d'Histoire Naturelle. pp 523.

Reubens, J.T., Braeckman, U., Vanaverbeke, J., Van Colen, C., Degraer, S., Vincx, M., 2013. Aggregation at windmill artificial reefs: CPUE of Atlantic cod (Gadus morhua) and pouting (Trisopterus luscus) at different habitats in the Belgian part of the North Sea. Fish. Res. 139, 28-34. doi:10.1016/j.fishres.2012.10.011

Reubens, J.T., Degraer, S., Vincx, M., 2014. The ecology of benthopelagic fishes at offshore wind farms: a synthesis of 4 years of research. Hydrobiologia 727, 121-136. doi:10.1007/s10750-013-1793-1

Reubens, J.T., Degraer, S., Vincx, M., 2011. Aggregation and feeding behaviour of pouting (Trisopterus luscus) at wind turbines in the Belgian part of the North Sea. Fish. Res. 108, 223-227. doi:10.1016/j.fishres.2010.11.025

Rombouts, I., Beaugrand, G., Fizzala, X., Gaill, F., Greenstreet, S.P.R., Lamare, S., Le Loc'h, F., McQuattersGollop, a., Mialet, B., Niquil, N., Percelay, J., Renaud, F., Rossberg, a. G., Féral, J.P., 2013. Food web indicators under the Marine Strategy Framework Directive: From complexity to simplicity? Ecol. Indic. 29, 246-254. doi:10.1016/j.ecolind.2012.12.021

Rybarczyk, H., Elkaïm, B., 2003. An analysis of the trophic network of a macrotidal estuary: The Seine Estuary (Eastern Channel, Normandy, France). Estuar. Coast. Shelf Sci. 58, 775-791. doi:10.1016/S02727714(03)00184-7

Rybarczyk, H., Ochs, L., Loquet, N., Elkaı"m, B. 2003. Analysis of the trophic network of a macrotidal ecosystem: the Bay of Somme (Eastern Channel). Estuar. Coast. Shelf Sci. doi:10.1016/S02727714(02)00294-9.

Salomon, J.C., Breton, M., 1991. Courants résiduels de marée dans la Manche. Oceanol. Acta. 11, 47-53.

Salomon, J.C., Breton, M., 1993. An atlas of long-term currents in the Channel. Oceanol. Acta. 16, 439-448.

Sanchez, F., Olaso, I., 2004. Effects of fisheries on the Cantabrian Sea shelf ecosystem. Ecol. Model. 172, 151174.

Scheidat, M., Tougaard, J., Brasseur, S., Carstensen, J., van Polanen Petel, T., Teilmann, J., Reijnders, P., 2011. Harbour porpoises ( Phocoena phocoena) and wind farms: a case study in the Dutch North Sea. Environ. Res. Lett. 6, 025102. doi:10.1088/1748-9326/6/2/025102

Shields, M.A., Payne, A.I.L., 2014. Marine renewable energy technology and environmental interactions, Humanity and the Sea. Springer Sciences. pp. 176.

Souissi, S., 2007. Etude du comportement natatoire, de la reproduction et du développement d'Eurytemora affinis: combinaison des approches expérimentale au laboratoire et in situ et modélisation. Seine-Aval Scientific Report 3, France, pp. 63.

Spitz, J., Richard, E., Meynier, L., Pusineri, C., Ridoux, V., 2006. Dietary plasticity of the oceanic striped dolphin, Stenella coeruleoalba, in the neritic waters of the Bay of Biscay. J. Sea Res. 55, 309-320. doi:10.1016/j.seares.2006.02.001

Spitz, J., Mourocq, E., Schoen, V., Ridoux, V., 2010. Proximate composition and energy content of forage species from the Bay of Biscay: high or lowquality food? ICES, J. Mar. Sci. 67, 909-915. doi:10.1093/icesjms/fsq008

Tecchio, S., Coll, M., Christensen, V., Company, J.B., Ramírez-Llodra, E., Sardà, F., 2013. Food web structure and vulnerability of a deep-sea ecosystem in the NW Mediterranean Sea. Deep Sea Res. Part I 75, 1-15. 
doi:10.1016/j.dsr.2013.01.003

Tecchio, S., Tous Rius, A., Dauvin, J.-C., Lobry, J., Lassalle, G., Morin, J., Bacq, N., Cachera, M., Chaalali, A., Villanueva, M.C., Niquil, N., 2015. The mosaic of habitats of the Seine estuary: Insights from food-web modelling and network analysis. Ecol. Modell. 312, 91-101. doi:10.1016/j.ecolmodel.2015.05.026

Trites, A.W., Pauly, D., 1998. Estimating mean body masses of marine mammals from maximum body lengths. Can. J. Zool. 76, 886-896.

Ulanowicz, R.E., 1986. Growth and Development: Ecosystems Phenomenology. Springer-Verlag, New York

Ulanowicz, R.E., 1992. Ecosystem health and trophic flow networks. In: Costanza R, Norton BG, Haskell BD (eds) Ecosystem health: new goals for environmental manage-ment. Island Press, Washington, DC, pp 190-225.

Ulanowicz, R.E., Puccia, C.J., 1990. Mixed trophic impacts in ecosystems. Coenoses 5, 7-16.

Vallet, C., 1997. Le compartiment suprabenthique des fonds circalittoraux de la manche : composition faunistique et quantitative, et role des transferts benthos/pelagos. Thèse de doctorat en Sciences biologiques et fondamentales appliquées. Psychologie, Paris. pp. 422.

Valls, A., Gascuel, D., Guénette, S., Francour, P., 2012. Modeling trophic interactions to assess the effects of a marine protected area: case study in the NW Mediterranean Sea. Mar. Ecol. Prog. Ser. 456, 201-214

Walters, C., Christensen, V., Pauly, D., 1997. Structuring dynamic models of exploited ecosystems from trophic mass-balance assessments. Rev. Fish Biol. Fish. 7, 139-172. doi:Doi 10.1023/A:1018479526149

Westerberg, H., Lagenfelt, I., 2008. Sub-sea power cables and the migration behaviour of the European eel. Fish. Manag. Ecol. 15, 369-375. doi:10.1111/j.1365-2400.2008.00630.x

Wilhelmsson, D., Malm, T., 2008. Fouling assemblages on offshore wind power plants and adjacent substrata. Estuar. Coast. Shelf Sci. 79, 459-466. doi:10.1016/j.ecss.2008.04.020

Wilhelmsson, D., Malm, T., Öhman, M.C., 2006. The influence of offshore windpower on demersal fish. ICES J. Mar. Sci. 63, 775-784. doi:10.1016/j.icesjms.2006.02.001

Wilhelmsson, D., Malm, T., Thompons, R., Tchou, J., Sarantakos, G., McCormick, N., Luitjens, S., Gullstrom, M., Patterson Edwards, J., Amir, O., Dubi, a, 2010. Greening Blue Energy : Iden fying and managing the biodiversity risks and opportuni es of o ff shore renewable energy Edited by Dan Wilhelmsson et al.

Wilson, J.G., Parkes, A., 1998. Network analysis of the energy flow through the Dublin Bay ecosystem. Proceedings of the Royal Irish Academy 98B, 179.

Wolfson, a, Van Blaricom, G., Davis, N., Lewbel, G., 1979. The Marine Life of an Offshore Oil Platform. Mar. Ecol. Prog. Ser. 1, 81-89. doi:10.3354/meps001081 
Figure 1. Position of the Courseulles-sur-mer offshore wind farm in the Bay of Seine, north-western France.

949 Figure 2. Functional groups of the Courseulles-sur-mer ecosystem model arranged using trophic levels as y950 axis and benthic/pelagic partitioning on the $x$-axis. Trophic levels are relative to the BOWF model, before the 951 construction. Functional groups written in blue and bold identify the functional groups for which the 952 biomasses have been set to their accumulated maximum during for the REEF scenario.

953 Figure 3. Mixed Trophic Impact (MTI) analysis performed on the BOWF model. Negative (red cells) and 954 positive (blue cells) overall impacts are represented.

955 Figure 4. Keystoneness index calculated for the two Ecopath models ("before" and "after" the construction 956 of the Courseulles-sur-mer offshore wind farm; BOWF model is in blue and REEF scenario is in green). The 957 size of the circles is proportional to the functional group biomass.

958 Figure 5. Lindeman spine plot of flows and biomasses and transfer efficiencies by discrete trophic levels for 959 the two Ecopath models.

960 Figure 6. Differences in compartment throughflows between the two Ecopath models. Note that the $y$-axis 961 scale is log-transformed, and that this percentage analysis did not consider the difference in absolute values 962 between functional groups. Grey bars identify functional groups for which the biomasses were set to their 963 accumulated maximum during the Ecosim 30-years simulation of 'Reef Effect'. Black bars represent groups 964 for which variations in biomass were an output of the simulation. 
967 Table 1. Biomass values, production over biomass $(\mathrm{P} / \mathrm{B})$ ratios, consumption over biomass $(\mathrm{Q} / \mathrm{B})$ ratios, and 968 Ecotrophic Efficiencies (EE) in the two Ecopath models ("before" and "after" the construction of the 969 Courseulles-sur-mer offshore wind farm in the Bay of Seine; BOWF model and REEF scenario, respectively). 970 Functional groups for which biomasses were set to their accumulated maximum in the REEF scenario are 971 marked in bold. Biomasses estimated in the BOWF model were indicated in grey and italic

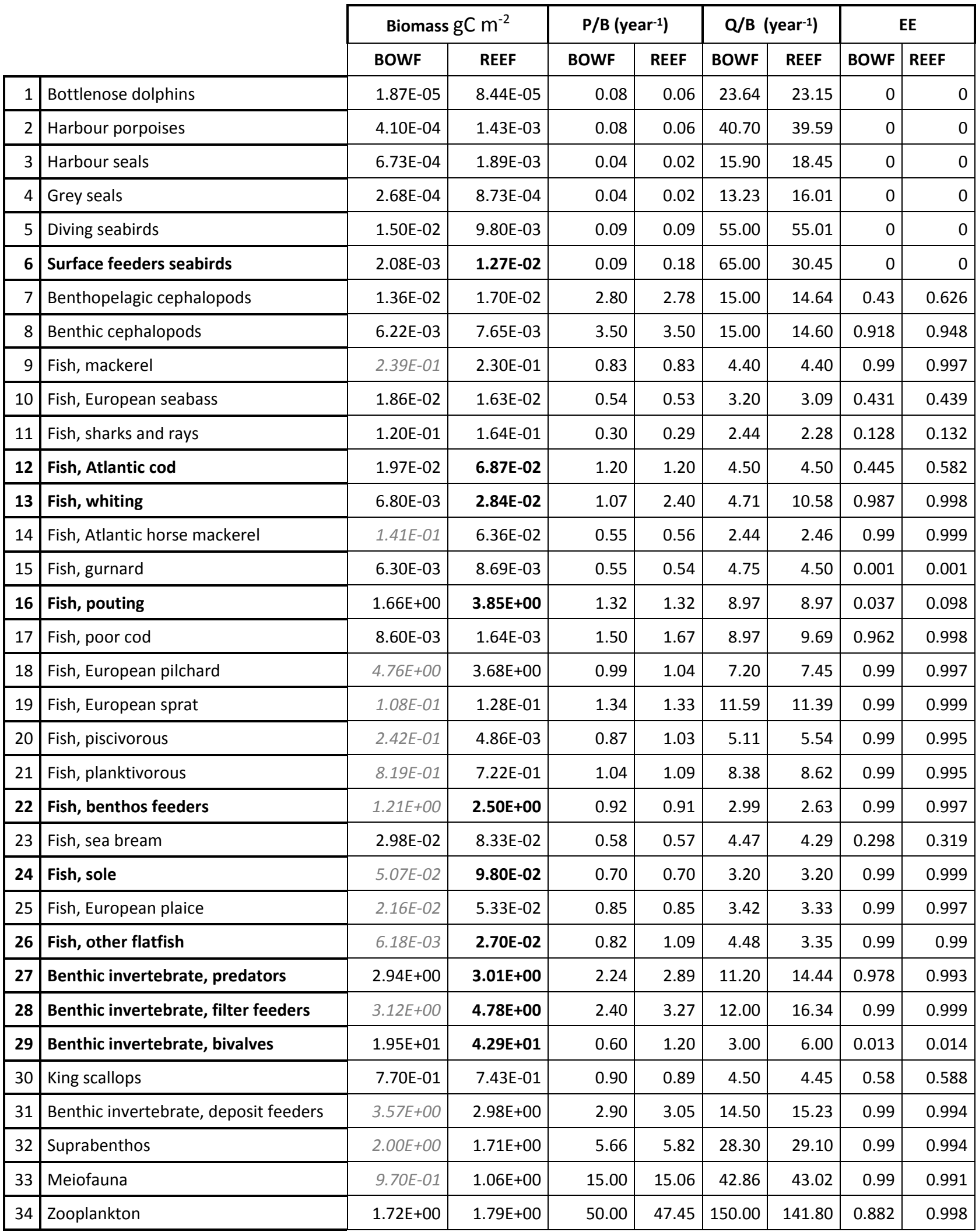




\begin{tabular}{|l|l|r|r|r|r|r|r|r|r|}
\cline { 2 - 8 } 35 & Bacteria & $7.50 \mathrm{E}-01$ & $7.70 \mathrm{E}-01$ & 72.80 & 72.34 & 145.60 & 144.68 & 0.219 & 0.246 \\
\hline 36 & Phytoplankton & $3.24 \mathrm{E}+00$ & $3.24 \mathrm{E}+00$ & 150.00 & 150.00 & & & 0.758 & 0.997 \\
\hline 37 & Detritus & $1.90 \mathrm{E}+01$ & $1.92 \mathrm{E}+01$ & & & & & & \\
\hline
\end{tabular}

974 Table 2. General system statistics and ENA indices for the BOWF model compared to values obtained for 975 similar Northern European systems. The Total System Throughput (T.., $\mathrm{gC} \mathrm{m}^{-2}$ year $^{-1}$ ) was calculated as the 976 sum of all the flows in the food web. The Finn's Cycling Index (FCl) gives the percentage of all flows generated 977 by cycling. The Ascendency (A) is a measure of the system activity (Total System Throughput) linked to its 978 degree of organization (Average Mutual Information) and is given in $\mathrm{gC} \mathrm{m}^{-2}$ year-1.

\begin{tabular}{|c|c|c|c|c|c|c|}
\hline Ecosystems & T.. & A & FCl & Biomass/Throughput & $\begin{array}{c}\text { Total living } \\
\text { biomass }\end{array}$ & $\begin{array}{c}\text { Reference for Ecopath } \\
\text { models }\end{array}$ \\
\hline Seine estuary & $\begin{array}{c}4584.92- \\
1161.05\end{array}$ & $\begin{array}{c}1442.6- \\
6058.6\end{array}$ & $3.65-20.65$ & $0.07-0.022$ & $10.23-40.40$ & Tecchio et al., 2015 \\
\hline Bay of Somme & 2312.1 & 2401.6 & 12.2 & 0.01 & 27.44 & Rybarczyck et al., 2003 \\
\hline BOWF model & 1607.616 & 1869.1 & 9.16 & 0.030 & 48.12 & \\
\hline REEF scenario & 1831,933 & 2156,9 & 12,86 & 0.041 & 74.73 & \\
\hline Dublin Bay & 724.69 & 848.5 & 31.9 & & & Wilson and Parkes, 1998 \\
\hline
\end{tabular}




\section{Figure 1}

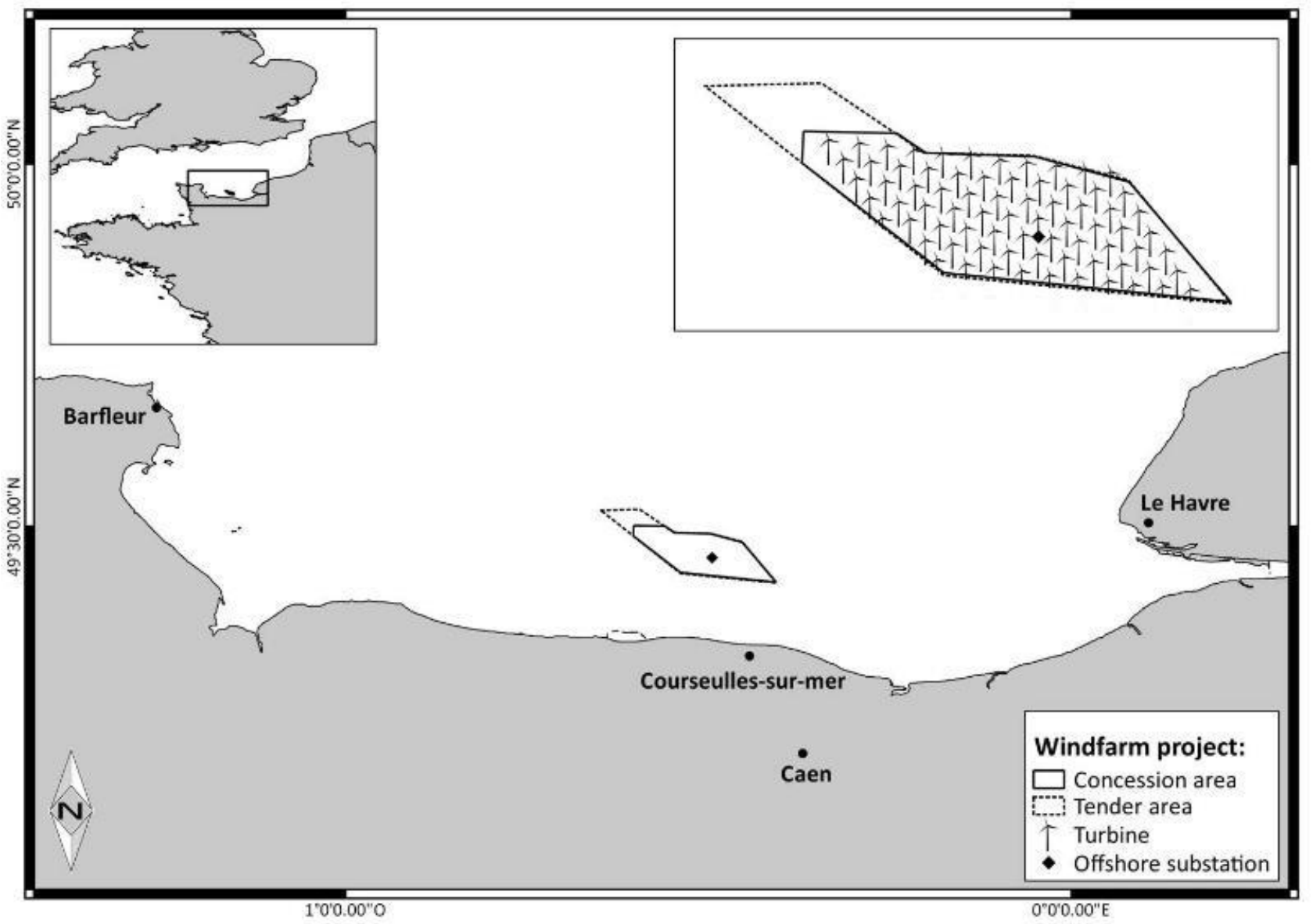


Figure 2

5

Bottlenose dolphins

Harbour porpoise

Grey and harbour seals

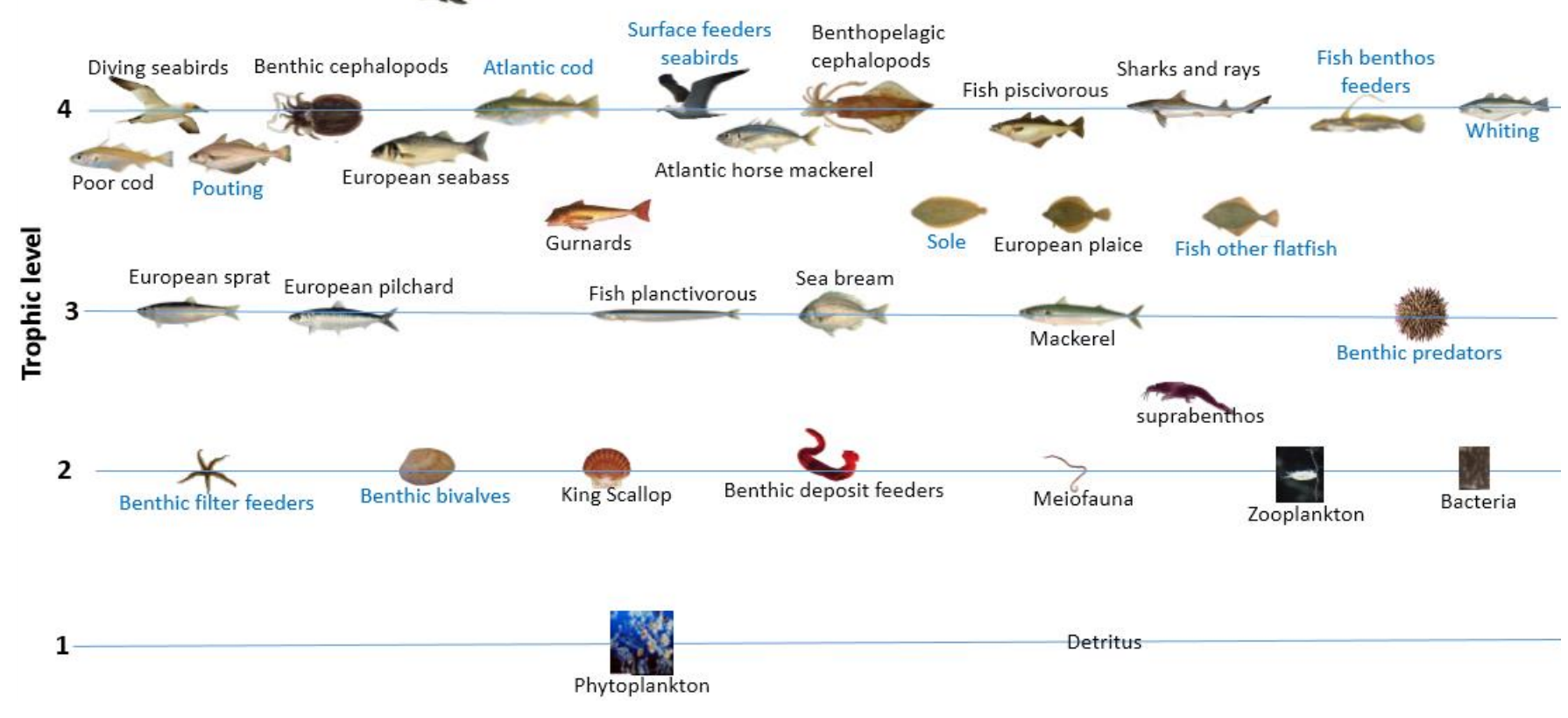




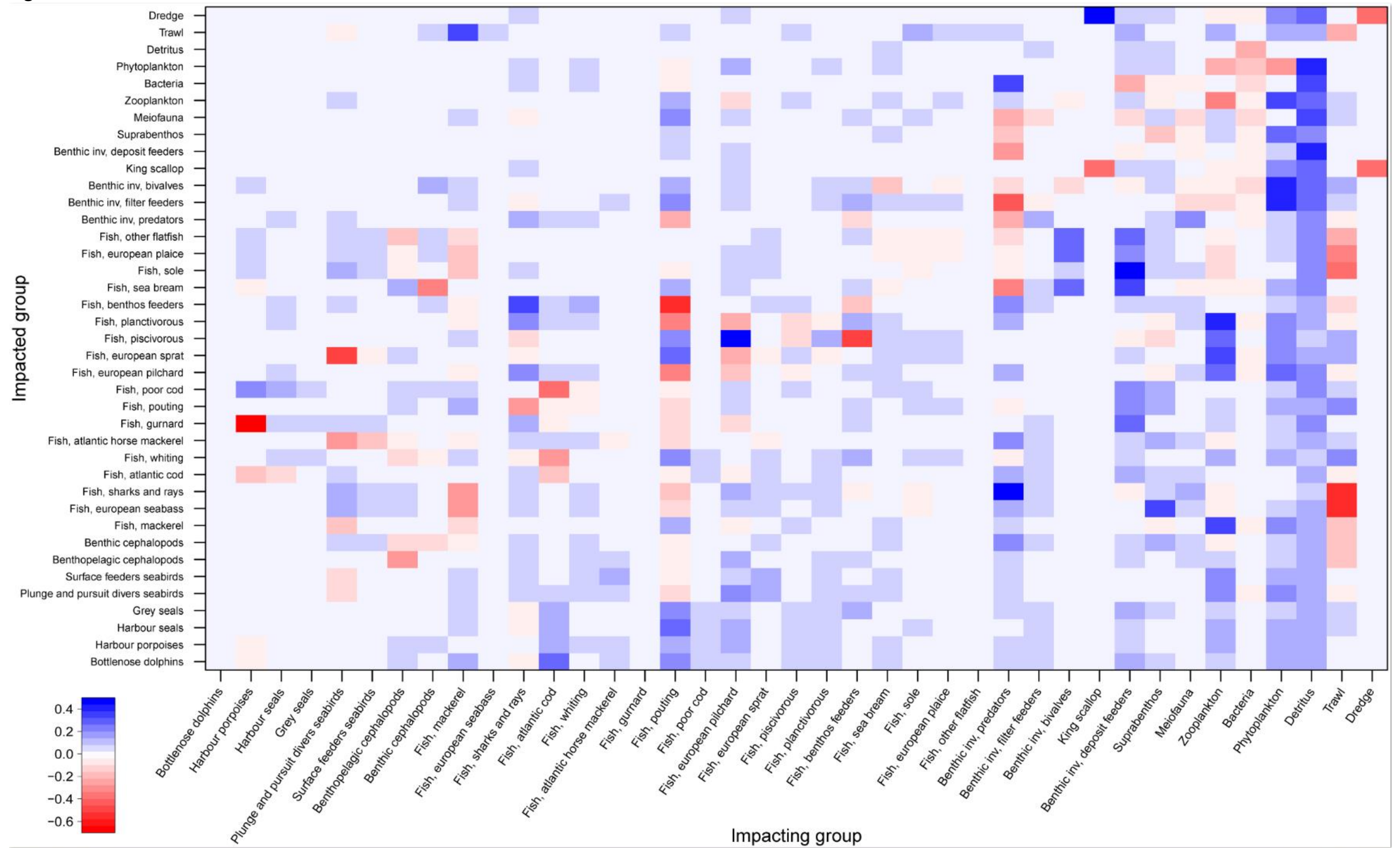


$991 \quad$ Figure 4

992

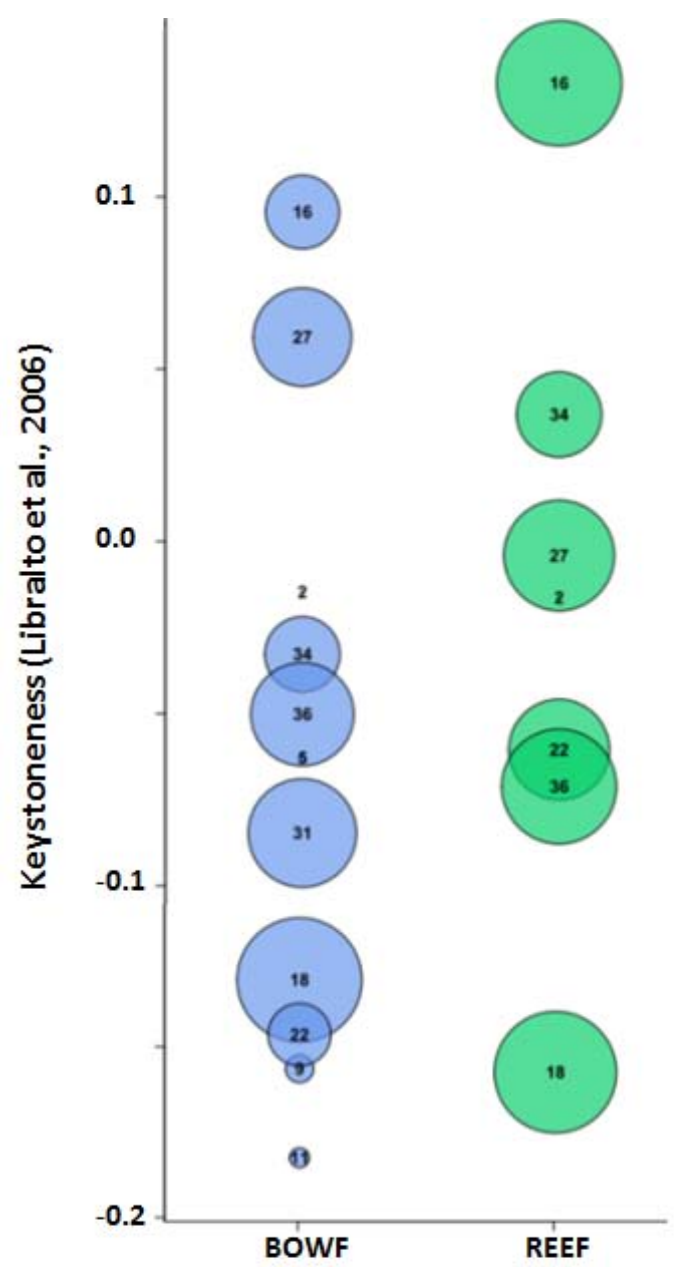

2 - Harbour porpoises

22 - Fish, benthos feeders

5 - Plunge and pursuit divers seabirds

27 - Benthic iny, predators

9 - Fish, mackerel

31 - Benthic irv, deposit feeders

11 - Fish, sharks and rays

34 - Zooplankton

16 - Fish, pouting

36-Phytoplankton 
$994 \quad$ Figure 5

995
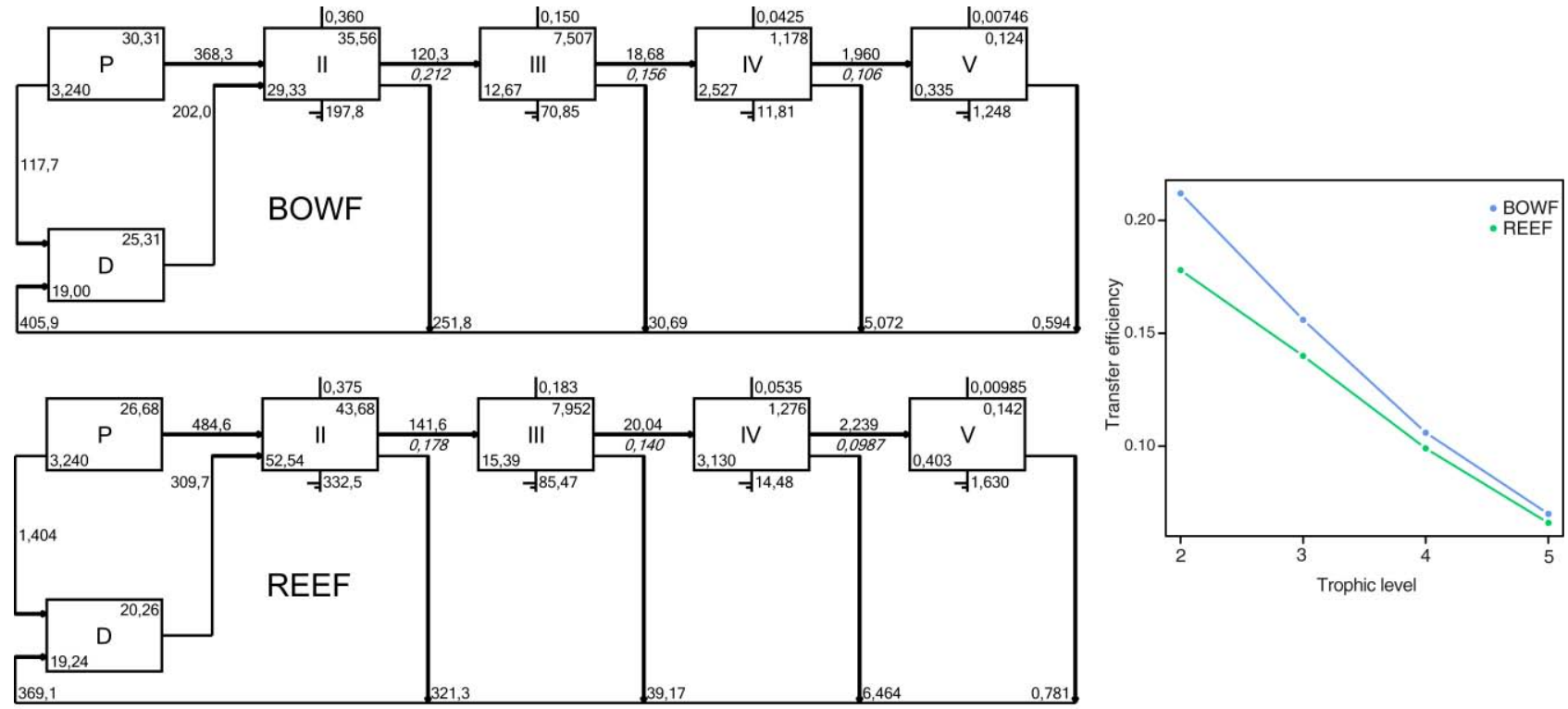

996

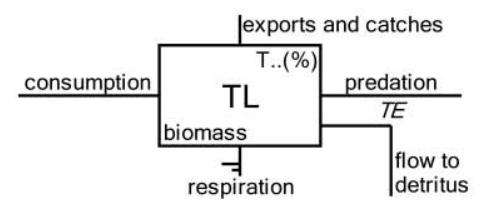


997

998

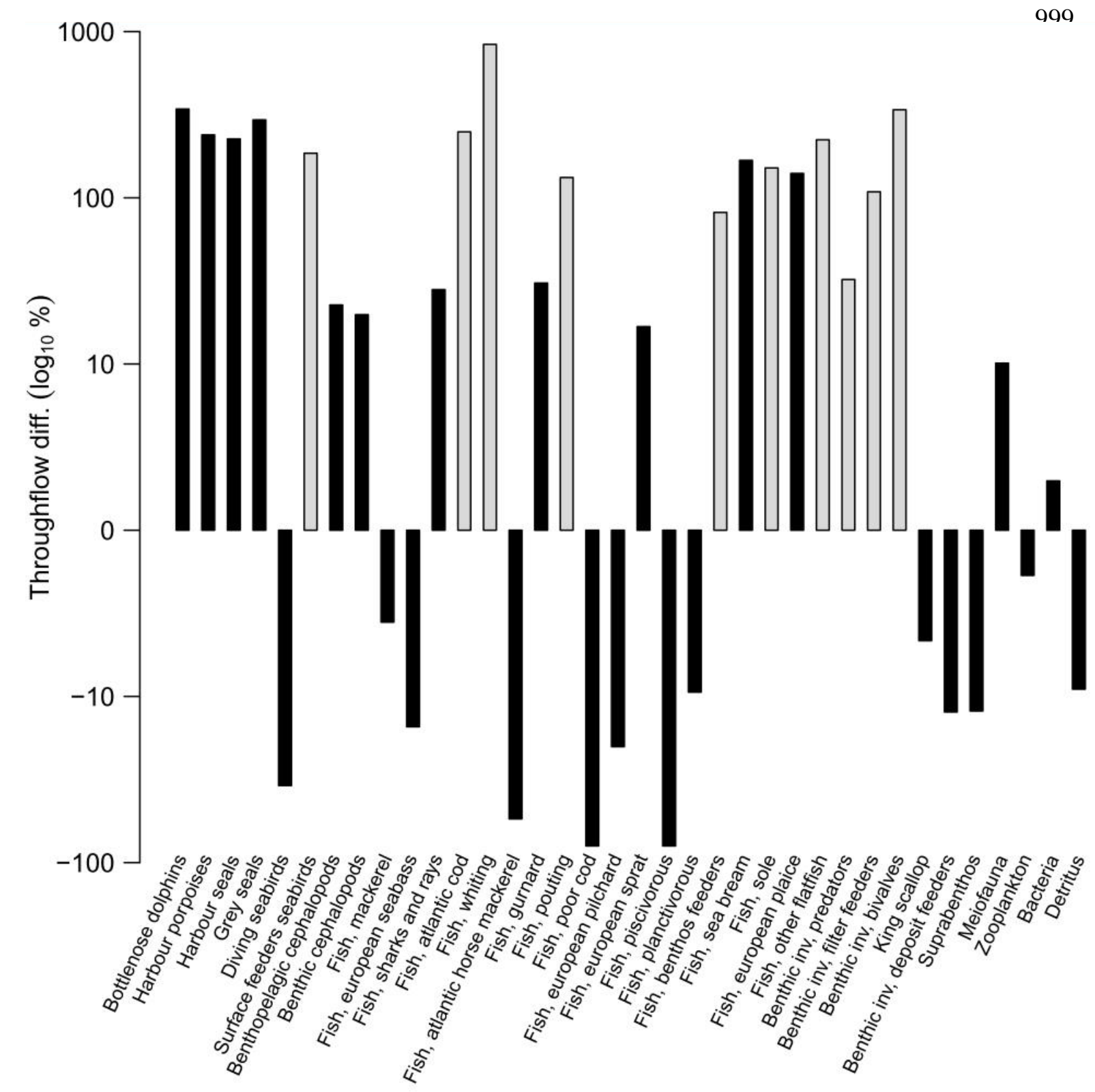

